\title{
LA TEORÍA DE LAS INMISIONES COMO FUNDAMENTO DOGMÁTICO DE LA PROTECCIÓN JURÍDICA PRIVADA ANTE EL RUIDO
}

[The Theory of Immissions as Dogmatic Grounds for the Private Juridical Protection Against Noise]

\author{
Jorge B. Tisné NiEMANN*
}

\begin{abstract}
RESUMEN
El ruido es una molestia endémica de la sociedad actual cuyas consecuencias afectan directamente a la persona. El derecho ajeno como límite legal de la propiedad encuentra en las relaciones de vecindad el marco jurídico para la teoría de las inmisiones. Su reconocimiento entre los actuales artículos del Código Civil resulta imprescindible para la idónea protección privada de los derechos e intereses de aquellos conculcados por turbaciones sonoras que impiden gozar pacíficamente de un inmueble.
\end{abstract}

\section{Palabras Clave}

Ruido - Propiedad - Relaciones de vecindad - Teoría de las inmisiones.

\begin{abstract}
Noise is an endemic nuisance of today's society, which consequences directly affect people. Other people's right as the legal limit of property finds in the neighborhood relations the juridical framework for the theory of immissions. Its acknowledgement among the current articles of the Civil Code is essential for due private protection of the rights and interests of people affected by uncomfortable noises that prevent them from peacefully enjoying a property.

\section{KeYwords}

Noise - Property - Neighborhood relationships - Theory of Immissions.
\end{abstract}

RECIBIDo el 12 de abril y ACEPTADo el 15 de mayo de 2013

* Alumno regular de Programa de Doctorado de la Universidad de los Andes. Dirección postal: Facultad de Derecho, Universidad de los Andes, Monseñor Álvaro de Portillo 12.455, Las Condes, Santiago, Chile. Correo electrónico: jbtisne@miuandes. cl-j_tisne@hotmail.com. Especial agradecimiento a la profesora Maite Aguirrezábal Grünstein por sus comentarios y opiniones. 


\section{INTRODUCCIÓN}

La concentración demográfica en Chile promueve la exacerbación de pugnas vecinales. Los ruidos, olores, vibraciones, entre otros fenómenos son importantes turbaciones que impiden vivir tranquilamente ${ }^{1}$.

Los particulares afectados por actividades vecinales o industriales molestas tienden a solicitar la protección de sus derechos e intereses mediante mecanismos legales diversos al ordenamiento jurídico civil ${ }^{2}$.

Por un lado, es común que se incoen recursos de protección fundados en distintos preceptos constitucionales que tienen por objeto exclusivamente el cese de las actividades molestas. Los afectados quedan sujetos a plazos y a un procedimiento especial carente de la posibilidad de solicitar indemnización.

Por otro lado, la regulación del ruido tiene un carácter inminentemente administrativo. Existe un heterogéneo cuerpo normativo diseminado en el ordenamiento público que hace alusión a la problemática, siendo los más relevantes al caso, el Decreto Supremo No 146, de 1997, denominado Norma de emisión de ruidos molestos generadospor fuentes fjjas, y las distintas ordenanzas municipales.

En el ámbito público, el afectado por ruidos podrá recurrir a los mecanismos establecidos en una normativa de difícil comprensión, quedando condicionado a resoluciones no siempre claras ni expeditas, tiempos de

${ }^{1}$ El "Estudio sobre la audición de la población chilena" realizado en el año 2012 por el Centro Auditivo Gaes informa que alrededor de un tercio de los chilenos ha experimentado molestias por ruidos producidos por sus vecinos. El $83 \%$ de los encuestados estima que vive en una ciudad ruidosa, existiendo una percepción mayor en la Región Metropolitana (87\%) que en regiones (72\%). Señala que los ruidos molestos provienen principalmente del tráfico vehicular (30\%), obras de construcción (20\%) y el volumen de la música (20\%), siendo particularmente en el hogar donde más incomo$\mathrm{da}$ sentirlo. Asimismo, describe que las fuentes sonoras vecinales que mayores molestias producen son el alto volumen de la música (68\%), uso de herramientas (14\%), gritos (6\%) y mascotas (6\%). Sorprende que $23 \%$ de los chilenos evite abrir ventanas para no ser molestado. Cfr., "Un tercio de los chilenos ha tenido problemas con vecinos por ruidos molestos" en El Mercurio Online, disponible en: http://www.emol.com/noticias/ nacional/2012/09/03/558730/un-tercio-de-los-chilenos-ha-tenido-problemas-convecinos-por-ruidos-molestos.html (consultado el 3 de septiembre de 2012).

${ }^{2}$ En el mismo sentido: Amunátegui Perelló, Carlos Felipe, Las relaciones de vecindad y la teoría de las inmisiones en el Código Civil, en Revista de Derecho de la Pontificia Universidad Católica de Chile, 38 (2012) 1, p. 80. Agrega como medio de protección la responsabilidad civil extracontractual pero da cuenta de las dificultades asociadas a la acreditación del elemento subjetivo del autor, la cuantía del daño y que en la mayoría de las ocasiones se persigue el cese de la molestia y no necesariamente un resarcimiento pecuniario. 
espera variables y a la disponibilidad de recursos y de personal que la administración del Estado disponga para el efecto. En definitiva, consideramos que no es conveniente que se tienda a evacuar los reclamos de la comunidad por ruidos a través de los entes públicos cuando en la gran mayoría de los casos simplemente existe un conflicto entre particulares.

El derecho de propiedad no es absoluto sino que se encuentra expresamente limitado por la ley y el derecho ajeno. Es en esta segunda limitación que se halla el fundamento de las relaciones de vecindad como ámbito de protección y de restricción para el carácter absoluto del dominio.

Las inmisiones son hechos que corrompen las relaciones de vecindad pues se basan en el principio que nadie puede hacer en lo suyo aquello que proyecte consecuencias negativas en lo ajeno. En consideración a la extendida y probada aplicabilidad de la teoría en los ordenamientos privados comparados, proponemos que su construcción dogmática es plausible en el nuestro conforme a las normas existentes en el Código Civil.

La teoría de las inmisiones es una idea innovadora que quiebra con el tratamiento histórico de la doctrina y la jurisprudencia nacional en torno a este tipo de perturbaciones prediales. Resulta trascendente en materia de ruidos, pues al ser un supuesto de inmisión, faculta al poseedor de un inmueble o a quienes tienen derechos reales constituidos en él a solicitar el cese de la actividad o la indemnización pertinente por concepto de turbación o molestia de la posesión.

En el presente trabajo expondremos los fundamentos dogmáticos de las modernas relaciones de vecindad en función del derecho ajeno como límite al derecho de propiedad. Asimismo abordaremos el origen, coherencia, concepto y consecuencias prácticas de las inmisiones como una teoría distinta al abuso del derecho en Chile. Finalmente ofreceremos un análisis pormenorizado del tratamiento actual del ruido en nuestro ordenamiento administrativo y los mecanismos jurídicos privados con los que cuenta el particular conculcado por ruidos intolerables en el inmueble del que es dueño o con el que tiene algún vínculo jurídico.

\section{LAS MODERNAS RELACIONES DE VECINDAD} Y LA DELIMITACIÓN DE UN CONCEPTO

Dispone el artículo 582 CC. que "El dominio (que se llama también propiedad) es el derecho real en una cosa corporal, para gozar y disponer de ella arbitrariamente; no siendo contra la ley o derecho ajeno. La propiedadseparada del goce de la cosa, se llama mera o nuda propiedad". Es el derecho real que ofrece las facultades más amplias respecto de un bien mueble o inmueble. Su 
naturaleza se explica pues tiende a satisfacer las necesidades económicas del individuo a través del aprovechamiento material y personal de la cosa ${ }^{3}$.

Conocidas son los tres caracteres del dominio ${ }^{4}$. Para efectos de nuestro estudio es el derecho ajeno como límite que gobierna al carácter absoluto de los actos del propietario el que merece mayores esfuerzos. Se han clasificado las restricciones del dominio como de utilidad pública y privada. Dentro de esta última se hallan las relaciones de vecindad5.

Dichas relaciones pueden ser concebidas como una aplicación del principio romano "alterum non laedere" a la compleja red de vínculos entre predios próximos. Tal como una persona no debe dañar a otra injustamente tampoco lo debe hacer el dueño o poseedor de un predio con sus pares. Las relaciones de vecindad encuentran su punto de partida en la proximidad de los predios, siendo una constante, la evolución que han experimentado desde los tiempos de la propiedad rural hasta la moderna sociedad industrializada ${ }^{6}$. Su estudio resulta menester toda vez que la inmediación ha sido históricamente campo fecundo de conflictos intervecinales ${ }^{7}$.

${ }^{3}$ Alessandri, Arturo - Somarriva, Manuel - Vodanovic, Antonio, Tratado de los derechos reales. Bienes (6 $6^{a}$ edición, Santiago, Editorial Jurídica de Chile, 2001), I, p. 35 n. 37.

${ }^{4}$ Ibíd., I, pp. 37-38 notas 41-44, en donde se aprecia que el carácter absoluto de la propiedad es el pleno poder reconocido al propietario para hacer o no hacer lo que estime un el bien. Sin embargo, este poder soberano de usar, gozar y disponer viene limitado por elementos intrínsecos expresamente consagrados por la norma, esto es, la ley y el derecho ajeno. El carácter exclusivo de la propiedad faculta al dueño para impedir que otro pretenda su derecho en la misma cosa, lo que no es óbice para la compatibilidad con otros derechos reales. Por el carácter perpetuo del dominio el derecho no se extingue por el paso del tiempo, la omisión de actos en la cosa o a pesar que un tercero alegue su dominio. La única forma de perderlo es mediante la prescripción adquisitiva por parte del tercero que la posea.

${ }^{5}$ Ibíd., I, p. 100, n. 136.

${ }^{6}$ En este sentido Algarra Prats, Esther, La defensa juridico-civil frente a humos, olores, ruidos y otras agresiones a la propiedad y a la persona, (Madrid, Mc-Graw-Hill, 1995), pp. 28-44.

${ }^{7}$ Hace ya varias décadas DíEz-PicAzo, Luis, Fundamentos del Derecho civil patrimonial (Madrid, Editorial Tecnos, 1983), II, p. 114, describía la integración de las propiedades en función del proceso de urbanización y comentaba que la relativa modernidad del tratamiento de las relaciones de vecindad se debía a la compresión de las áreas dominicales y la tecnología. Sin perjuicio de la extensión de la cita, la sencillez y lucidez de su redacción nos anima a transcribir el siguiente pasaje del autor. "El proceso de urbanización, sea del tipo que fuera, presupone la creación de zonas (áreas, polígonos, etc.) y la consiguiente integración en ellas de las propiedades radicadas en el sector. La propiedad tradicional era soberana, pero para ser soberana tenía que ser un ente independiente y solitario. Mi propiedad es mi reino, mi castillo, decía un antiguo adagio. Los castillos solo se conciben en lo alto de una cresta o de un roquedo, con un foso que 
El pleno poder del dueño en su propiedad debe ser matizado por los derechos de sus vecinos toda vez que participa de una sociedad en la cual confluyen variedad de intereses ${ }^{8}$. La relación con el prójimo es forzosa debiendo meditar recaudos para impedir la producción de turbaciones que extralimiten los deslindes de su propiedad. El poder de dominio es pleno en la medida que se ajuste a las leyes y se ejerza en el predio propio'. A contrario sensu, "[...] el derecho de propiedad no autoriza para hacer todo lo que se quiera en la cosa o con la cosa en que se ejercita, sin excepción alguna; sino que la disposición arbitraria de la cosa tiene su límite en el derecho ajeno, que no puede ser dañado impunemente" 10 .

El ejercicio del dominio no puede interferir con el legítimo derecho ajeno. La intromisión voluntaria o involuntaria es parte de la convivencia humana. La comunión de intereses sobre un espacio determinado dificulta el respeto y solidaridad entre vecinos. El disfrute propio puede generar una intromisión

los circunda y los separa del resto del mundo. Los reinos estaban siempre detrás de una frontera inviolable. En la actualidad, los reinos han tenido que integrarse en las comunidades supranacionales perdiendo buena parte de su soberanía. Y los castillos son un puro anacronismo, que sirven sólo para deleitar a sus amigos. El carácter independiente y solitario de la propiedad tradicional hacía que sus relaciones en el mundo exterior, en cuanto tal propiedad, fueran inexistentes o, todo lo más, episódicas. Cuando se producían, estas relaciones eran fundamentalmente 'relaciones de vecindad', que traducidas al lenguaje jurídico son siempre relaciones de mala vecindad, es decir, relaciones de tensión y conflicto. La buena vecindad no necesita del Derecho. Cuando los vecinos echan mano al Derecho es porque no se llevan bien [...] Otras veces se trata de inmisiones nocivas, que la jurisprudencia tuvo que ir regulando trabajosamente, ajustando el comportamiento al criterio de la conformidad al destino normal de los fundos y al criterio de la diligencia media, creando conceptos como el de 'obligaciones ordinarias de la vecindad' o el de las 'precauciones necesarias para prevenir inconvenientes'”.

${ }^{8}$ Macías Castillo, Agustín, El daño causado por el ruido y otras inmisiones (Madrid, La Ley, 2004), p. 133, expone que "el propio concepto de relaciones de vecindad es contingente y variable" en virtud que estos atributos responden al constante cambio que pueden experimentar los hechos materiales e inmateriales que dan lugar a su problemática y, asimismo, a la dispersión de su normativa. Supone el constante cambio de los hechos que las configuran, los cuales se complejizan con el avance de las tecnologías.

${ }^{9}$ Precisamente Algarra Prats, E., cit. (n. 6), p. 4 esta idea en las siguientes palabras, “[...] los lugares no son independientes, no están ubicados espacialmente de manera aislada, sino que necesariamente limitan unos con otros; además no es posible cerrarlos herméticamente para sustraerlos de toda influencia ajena o para evitar que los efectos de algunas de las actividades que se llevan a cabo en ellos no trasciendan en absoluta al exterior".

${ }^{10}$ Claro Solar, Luis, Explicaciones de derecho civil chileno y comparado (Santiago, Imprenta Nascimento, 1930), VI, p. 359 n. 306. 
ilícita en la heredad próxima que el vecino no debe estar obligado a soportar por disposición de ley o por acuerdo de voluntades (servidumbres).

El derecho ajeno como límite intrínseco de la propiedad es fuente de restricciones al ejercicio absoluto del dominio y constituye una obligación recíproca entre propietarios de inmuebles cercanos ${ }^{11}$. Estas restricciones se consideran obligaciones que decantan de las relaciones de vecindad y dogmáticamente han sido atribuidas a diversos fundamentos jurídicos, tales como un cuasicontrato de vecindad, servidumbres naturales o legales y delitos o cuasidelitos imputables autor del perjuicio ${ }^{12}$.

Las modernas relaciones de vecindad, proyectadas desde los comienzos de la industrialización, tienen características que las distinguen de los vínculos vecinales de antaño.

En la actualidad, éstas difícilmente pueden estar sujetas exclusivamente a la colindancia de las propiedades. La convivencia en una sociedad implica que las invasiones prediales pueden proyectarse más allá del predio aledaño. Independiente de la proximidad, la relación entre pares debe construirse en función de la potencial "zona de influencia"13. Las inmisiones tienen la potencialidad de perturbar a una comunidad completa y no exclusivamente al predio inmediato. Los nuevos supuestos exigen que se observe la vecindad

${ }^{11}$ Para un acercamiento en nuestra doctrina véase: PeÑaIlillo Arévalo, Daniel, Los bienes. La propiedad y otros derechos reales (Santiago, Editorial Jurídica de Chile, 2006), pp. 147-149 n. 64. El autor señala que las relaciones de vecindad se regulan en normas diseminadas en todo el ordenamiento y en general un cuerpo orgánico que pretenda congregarlas difícilmente cumplirá con su misión puesto que es prácticamente imposible que ofrezca respuesta para cada fricción vecinal. Sin embargo dicho esfuerzo ha sido realizado en nuestro país, no obstante el transcurso del tiempo y los cambios legislativos lo han relegado al desuso. Véase: Pescio Vargas, Victorio, La vecindad (Santiago, Editorial Jurídica de Chile, 1952).

${ }^{12}$ Para quien pretenda profundizar en esta materia, véase: Claro Solar, L., Explicaciones, cit. (n. 10), VI, pp. 358-359 n. 305; Navarro Mendizabal, I. A., Las inmisiones y molestias medioambientales. Tutela civil preventiva (Madrid, Editorial Dykinson, 1996), pp. 171-189.

${ }^{13}$ Algarra Prats, E., cit. (n. 6), p. 51. Comulgamos con el autor cuando dispone que no toda cercanía debe considerarse vecindad sino que es menester delimitar el concepto. A pesar que la idea de vecindad mundial podría producir el regocijo de algunos, estimamos que no es jurídicamente apropiado. El ámbito de influencia de una actividad asoma como un criterio idóneo de delimitación. Será en el caso concreto que deberá ser determinado. En consecuencia, el inmueble destinado al descanso de una familia estará sujeto a una relación de vecindad de menor escala que una empresa faenadora de animales pues su capacidad de perturbar otros predios es considerablemente mayor. La influencia estará determinada por tres elementos: el uso del inmueble, ámbito de expansión de sus efectos y relación de causalidad. 
ya no desde una perspectiva de colindancia sino de afección ${ }^{14}$. El ámbito de vecindad a la que el poseedor del predio estará sujeto variará respecto de su capacidad para perturbar a otros.

Asimismo, los problemas de vecindad contemporáneos no dicen relación directa con el dueño del inmueble involucrado sino con el poseedor material que lo usa o goza ${ }^{15}$. Desligar las relaciones de vecindad del estricto concepto de propietario ha sido considerado un progreso evolutivo denominado "la espiritualización de las relaciones de vecindad"16.

La calidad de vecino ha tomado protagonismo en desmedro de la concepción clásica del propietario como único sujeto capaz de pretender la protección de la propiedad. La holgura del concepto modifica la óptica real de la situación a una obligacional de derechos personales porque el vínculo vecinal ya no es meramente de predios próximos sino de las personas que los aprovechan ${ }^{17}$. Sin embargo el límite a la espiritualización del concepto lo expone Navarro al señalar que sería absurdo entender que existen relaciones de vecindad entre el pleno propietario y el nudo propietario porque atentaría contra el mismo fundamento del concepto. Debe tratarse de titulares de derechos reales sobre propiedades distintas ${ }^{18}$.

Los efectos de la mala convivencia superan la esfera real de los predios. El concepto de vecino admite una cuerpo de personas ligadas a un inmue-

${ }^{14}$ La Real Academia española, en Diccionario de la Lengua Española (22a edición, 2001), II, p. 2.273, define "vecindad" en los siguientes términos: "Conjunto de las personas que viven en las distintas viviendas de una misma casa, o en varias inmediatas las unas de las otras". Extraemos tres elementos identificadores que determinan la vecindad. El primero es que el elemento central son las personas y no los inmuebles. El segundo es el hecho de habitarlos sin trascender el título jurídico que lo justifique. El tercero dice relación con la inmediatez de los inmuebles. Consideramos relevante distinguir entre vecindad y relaciones de vecindad. La vecindad está constituida por aquellos que viven en inmuebles cercanos. Las relaciones de vecindad es un concepto más amplio que abarca no solo a quienes viven, sino a todos aquellos que gozan de vínculo jurídico sobre los inmuebles. Algarra Prats, E., cit. (n. 6), p. 47, agrega a la distinción el denominado derecho de vecindad que sería la "reglamentación positiva del derecho de vecindad" y estima que en la descripción normativa se vislumbra la delimitación de las relaciones.

${ }^{15}$ Macías Castillo, A., cit. (n. 8), p. 135, expone que las clásicas definiciones de relaciones de vecindad tendían a un concepto cosificado e identificado con el derecho de propiedad sin embargo dicha postura ha sido eventualmente superada.

${ }^{16}$ Macías Castillo, A., cit. (n. 8), p. 135.

${ }^{17}$ En este mismo sentido: Alessandri, A. - Somarriva, M. - Vodanovic, A., Tratado, cit. (n. 3), I, p. 100, n. 136 quien cita a SAVAtier, Cours de Droit Civil (Paris, 1947), p. 341 n. 663 al disponer que "tales relaciones o derechos se estudian habitualmente con motivo de la propiedad de los inmuebles; pero los problemas son idénticos si los vecinos son simples arrendatarios o usuarios".

${ }^{18}$ Navarro Mendizabal, I. A., cit. (n. 12), pp. 28-29. 
ble considerablemente mayor al exclusivo propietario. Por lo tanto resulta adecuado apartarnos de una concepción vecinal en términos jurídico-real y acoger una jurídico-obligacional ${ }^{19}$.

De hecho, el Diccionario de la Real Academia Española define la voz "vecino" en los siguientes términos: "Que habita con otros en un mismo pueblo, barrio o casa, en habitación independiente" 20 .

Se desprende de la definición que la relación no se erige en función del título de propiedad sino de la proximidad entre aquellos que utilizan un inmueble para su habitación. Sin embargo estimamos que la relación de vecino no debe reducirse a la habitación sino al ejercicio de los actos posesorios en éstos, independiente del titular.

La existencia de heredades próximas siempre será la piedra angular en que se edifica las relaciones de vecindad. A contrario sensu, el aislamiento de los fundos no deviene en relación alguna. El contenido del concepto no debe limitarse a la propiedad toda vez que inmanentemente comprende realidades aún más relevantes que el propio dominio. La persona es por excelencia quien debe aprovecharse de un inmueble y las afecciones que sufra en el marco de las relaciones de vecindad deben interesarle al Derecho ${ }^{21}$.

Las proyecciones de fenómenos como ruidos, olores o vibraciones perjudican a todo quién posea u ostente algún título jurídico sobre el inmueble. El efecto horizontal de la turbación tiende a equiparar a los vecinos. El propietario es tan vulnerable en sus derechos como el poseedor, usufructuario o mero tenedor. Tampoco es relevante el título de quién produce la molestia. El afectado solo requiere tener una relación con el inmueble, indiferente de su envergadura jurídica, y experimentar un menoscabo patrimonial o personal producto de la turbulencia ${ }^{22}$.

Concluye el tema de manera precisa y clara Macías en las siguientes palabras: "En buena lógica, las relaciones de vecindad tienen que ser, preci-

${ }^{19}$ Macías Castillo, A., cit. (n. 8), pp. 272-273.

${ }^{20}$ Diccionario de la Lengua Española (22a edición, 2001), II, p. 2.274.

${ }^{21}$ Algarra Prats, E., cit. (n. 6), p. 49.

${ }^{22}$ Encontramos sustento para la lectura sociabilizadora de las inmisiones en las palabras de BECK, Ulrich, La sociedad del riesgo. Hacia una nueva modernidad (Barcelona, Paidos, 1998), p. 42. "Dicho con una fórmula: la miseria es jerárquica, el smog es democrático. Con la extensión de los riesgos de la modernización (con la puesta en peligro de la naturaleza, de la salud, de la alimentación, etc.) se relativizan las diferencias y los límites sociales. De ahí se siguen extrayendo consecuencias muy diversas. Sin embargo, objetivamente los riesgos despliegan dentro de su radio de acción y entre los afectados por ellos, un efecto igualador. Ahí reside precisamente su novedosa fuerza política. En este sentido, las sociedades de riesgo no son sociedades de clases; sus situaciones de peligro no se pueden pensar como situaciones de clases, ni sus conflictos como conflictos de clases". 
samente, eso: relaciones entre vecinos. Que concreto título otorgue al vecino la condición de tal es un segundo escalón en el análisis"23.

Es evidente que el rigor de la problemática radica en la potencial afección de los vecinos por sobre el perjuicio material de las fincas. La convergencia de otros bienes jurídicos en dichas relaciones supera con creces el marco jurídico de la propiedad. El medio ambiente y la salud son bienes vinculados a la protección de la persona que evidencian la naturaleza interdisciplinar del asunto y su trascendencia constitucional.

Es por esto que identificamos funciones gemelas que hemos denominado la doble cara de la moneda vecinal. Por un lado, constituyen un límite al ejercicio de derechos reales en virtud de la convivencia entre pares. La restricción de facultades esta dado por la delimitación del inmueble. Materialmente, el problema se observa en cuestiones relativas a la colindancia. Accesión, plantación o construcción en terreno ajeno dice relación con un problema de delimitación predial. Lo mismo sucede al lanzar objetos o al ingresar en predio extraño.

Pero las relaciones de vecindad no se agotan en estos supuestos de ataques directos a la propiedad. Probablemente son aquellos efectos indeseados o ignorados que actualmente provocan el enriquecimiento del concepto en estudio. Las molestias indirectas que se sufren en el predio propio a causa de actividades ajenas constituyen el gran desafío para las relaciones de vecindad en la actualidad ${ }^{24}$. El concepto debe ser capaz de abrazar estas realidades de forma cierta. En este sentido, la segunda función que cumplen las relaciones de vecindad es de control para quien sufre las injerencias extrañas pues con el objeto de proteger sus legítimos intereses el conculcado podrá exigir el cese de la molestia ${ }^{25}$.

${ }^{23}$ Macías Castillo, A., cit. (n. 8), p. 136.

${ }^{24}$ Hace énfasis Appert, M. Georges, De los derechos del propietario respecto de sus vecinos, ahora, en Tavolari, Raúl (director), Revista de Derecho y Jurisprudencia. Ediciones Bicentenario. Doctrinas esenciales, Derecho Civil, Bienes (Santiago, Thomson Reuters - Puntolex, 2010), p. 209, en que las relaciones de vecindad son una materia delicada porque "los casos son infinitamente variados, las ocasiones de conflicto, interminables, las disposiciones legales muy escasas". Resulta interesante el trabajo descriptivo que realiza respecto del desarrollo jurisprudencial de la problemática asociada a la materia en Francia durante el siglo XIX, especialmente respecto de la actividad industrial.

${ }^{25}$ Algarra Prats, E., cit. (n. 6), pp. 51-52, describe que "en orden de su contenido normativo, el Derecho de vecindad tiene como especial característica su doble vertiente real y obligacional, que se aprecia especialmente en los sistemas español y francés. Las relaciones de vecindad deben ser objeto de estudio en el Derecho de bienes, pero sin olvidar su especificidad propia, que obliga a acudir también, en el campo civil, al Derecho de obligaciones, concretamente, la responsabilidad civil extracontractual [...] 
En nuestro ordenamiento carecemos de una definición de relaciones de vecindad por lo que nos parece oportuno señalar que por ellas entendemos el marco jurídico interdisciplinar constituido por normas y principios que tiene por objeto la protección mediata de la propiedad y la persona e inmediata del medio ambiente a través de la orientación de las acciones humanas en los inmuebles, procurando prevenir que la actividad de algunos genere dentro de su ámbito de afectación invasiones de cualquier tipo en propiedades ajenas que supongan conculcar los derechos o intereses de quienes las aprovechan, independiente de la calidad jurídica que se tenga respecto de los predios, siendo su fin último procurar la tolerable convivencia entre vecinos.

En los vínculos vecinales, el ejercicio del derecho de propiedad puede ocasionar daños a otros dueños a través de dos situaciones. En primer lugar, el causado por negligencia o malicia del propietario a través de ataques directos. En segundo lugar, el correspondiente a consecuencias indirectas del ejercicio del derecho de propiedad que impide mediante turbaciones el goce en predios vecinos.

En definitiva estas dos situaciones son las que explican la razón del derecho ajeno como límite a la propiedad. La invasión a predios vecinos supone la incitación de una coyuntura que al Derecho interesa, esto es, la mala vecindad $^{26}$. El conflicto, entonces, se origina entre dos derechos de dominio análogos pero de titulares distintos.

Las teorías que se han utilizado para dar fundamento dogmático a estas situaciones son la teoría del abuso del derecho y la teoría de las inmisiones respectivamente. Ésta recogida por nuestra doctrina, mas no así aquella ${ }^{27}$.

El contenido obligacional y real de las relaciones de vecindad se traduce en el otorgamiento de acciones personales y reales para la defensa de las mismas: la acción indemnizatoria de daños y perjuicios y la acción negatoria, como dos de los mecanismos de protección y defensa de importancia, también, en la lucha contra las inmisiones".

${ }^{26}$ De hecho la Real Academia Española, Diccionario de la Lengua Española, (22a edición, 2001), II, p. 2.273, define "hacer mala vecindad" como "ser molesto o perjudicial a los vecinos".

${ }^{27} \mathrm{El}$ derecho ajeno como fuente de restricciones al goce de la propiedad encuentra respaldo en nuestra doctrina civil en el abuso del derecho, tal como se observa en CLARo Solar, L., Explicaciones, cit. (n. 10), VI, pp. 350-359 n. 301; relegando al olvido la teoría de las inmisiones. La dogmática nacional ha sido influenciada por los orígenes de la doctrina francesa. Macías Castillo, A., cit. (n. 8), pp. 78-81, explica que al carecer de una norma expresa sobre solución de conflictos por inmisiones, la doctrina francesa optó por fundamentarla en el abuso del derecho. Con posterioridad, esta postura fue complementada mediante la doctrina de les troubles de voisinage que en resumidas cuentas es un sistema de responsabilidad extracontractual especial. Concluye que ha sido la jurisprudencia emanada de los tribunales franceses que perfeccionó en definitiva el desarrollo de las soluciones vecinales tanto desde la perspectiva resarcitoria como en la tutela inhibitoria. 
Es importante poner de manifiesto la distinción pues el alcance y objeto de cada cual es diferente.

La teoría del abuso del derecho que ha sido tradicionalmente utilizada indistintamente para los supuestos de perturbaciones vecinales, tiene por objeto reparar aquellos actos que mediante conductas antijurídicas, dolosas o culposas, provocan daños a otros. Es una idea que excede al campo de los conflictos vecinales y cuya aplicación informa al ordenamiento público y privado.

Por su parte, la teoría de la las inmisiones supone un ámbito de aplicación más acotado pues es atribuible únicamente a determinados hechos constitutivos de conflictos vecinales que forzosamente dicen relación con impedir el libre uso y goce de una propiedad ajena mediante proyecciones. Tiene por objeto fundamentalmente la tutela inhibitoria o preventiva pero además, particularmente en nuestro ordenamiento, compete una finalidad resarcitoria del daño producido por estos hechos ${ }^{28}$.

\section{LA TEORÍA DE LAS INMISIONES}

\section{El origen de la teoría de las inmisiones.}

Para comprender el origen de la teoría es preciso señalar que "el Derecho romano no formuló al respecto ningún criterio general; pero la casuística de sus jurisconsultos trata diversos casos de vecindad"29. En el Digesto, múltiples son las materias sometidas al conocimiento de los juristas que pueden atribuirse a casos de situaciones inmisivas ${ }^{30}$. Sin embargo es Dig.

${ }^{28}$ A diferencia de Amunátegui Perelló, C. F., No siendo contra derecho ajeno: hacia la formulación de una teoría de las inmisiones en nuestro código civil, en Revista Chilena de Derecho, 36 (2009) 3, p. 512; y Amunátegui Perelló, C. F., El artículo 921 del Código Civil y la querella de amparo. Posibilidad de exigir indemnizaciones a propósito de actos inmisivos, ahora, en CoRRAL TALCIANI, Hernán y otros (editores), Estudios de Derecho civil. Jornadas de Derecho Civil 2005-2009 (Santiago, LegalPublishing Chile 2011), I, p. 691, propone que el único objeto de la teoría es la tutela inhibitoria, esto es, la cesación de las consecuencias negativas proyectadas en el predio vecino a causa de actividades ajenas, pues la sitúa en el ámbito de derechos reales y no obligacionales. Es interesante la cuestión toda vez que de no mediar una tutela resarcitoria nos es difícil explicar cómo el autor puede defender la tesis que la querella de amparo que supone una indemnización es procedente por actos inmisivos, y más aún, mediante una responsabilidad objetiva. A mayor abundamiento. Claro Solar, L., Explicaciones, cit. (n. 10), VI, pp. 349-352 n. 300-302, también atribuye una responsabilidad sin culpa a los daños causados por las injerencias recíprocas a las que están sometidos los vecinos.

${ }^{29}$ Alessandri, A. - Somarriva, M. - Vodanovic, A., Tratado, cit. (n. 3), I, p. 101 n. 139.

${ }^{30}$ Recomendamos Algarra Prats, E., cit. (n. 6), pp. 194-208, para un acabado estudio de la inmissio en las fuentes romanas. 
$8,5,8,5$ el que ha servido de piedra angular para la construcción de la teoría de la inmisión o inmissio.

Dicha fuente describe la situación del dueño de un departamento que ha sido turbado en su posesión por los olores que expele una fábrica de quesos vecina. La traducción del texto es el siguiente: “[Ulpiano libro decimoséptimo al edicto] Aristón respondió a Cerelio Vital que no pensaba que hubiese derecho a expeler humo desde la taberna de quesos hacia los edificios superiores, salvo que existiese tal servidumbre. Igualmente dijo que desde los edificios superiores a los inferiores tampoco es lícito echar agua ni alguna otra cosa, porque solo es lícito hacer alguna cosa en lo suyo en cuanto no se proyecte en lo ajeno y la del humo, como la del agua es una inmisión. Por tanto, el del edificio superior puede litigar con el del inferior alegando que este no tiene derecho a hacer tal cosa. Finalmente, dice Aristón que escribió Alfeno que igualmente se puede demandar alegando que el otro no tiene derecho a extraer piedra en su propiedad de tal forma que los fragmentos caigan en mi fundo. Dijo Aristón al que tomó la fábrica de quesos en arrendamiento a los minturnenses que los de los edificios superiores le pueden prohibir la inmisión de humos, pero que él puede demandar a los minturnenses por el arrendamiento y que puede demandarse al que inmite humo alegando que no tiene derecho para hacerlo. Por el contrario, se puede demandar alegando que hay derecho para emitirlo, lo que se ve que también aprueba Aristón. Pero también puede tener lugar el interdicto uti possidetis si se prohíbe a alguien usar de lo suyo como quiera" 31 .

Del pasaje se extrae la prohibición de causar un mal al predio ajeno cuando no existe una servidumbre que así lo permita. La servidumbre es un reflejo de la libertad contractual mediante el cual los dueños de distintos predios podrán pactar voluntariamente (artículo 880 CC.) el gravamen de tolerar algún tipo de inmisión, estableciendo derechos y deberes para las partes. Es notable la expresión solo es lícito hacer alguna cosa en lo suyo en cuanto no se proyecte en lo ajeno ("in suo enim alii hactenus facere licet, quatenus nibil in alienum immittat") pues es el fundamento mismo de la teoría. "Dicha teoría no es más que una deducción lógica del carácter absoluto que tiene la propiedad en el mundo romano y, como tal, conlleva la ventaja de establecer una demarcación del uso de las cosas. No basta con que una persona se abstenga de realizar actos en lo ajeno ("facere in alieno"), sino que ni siquiera le resulta legítimo un hacer en lo propio ("facere in suo") si las consecuencias de su actividad repercuten en lo ajeno"32.

${ }^{31}$ Amunátegui Perelló, C. F., No siendo contra derecho ajeno, cit. (n. 28), p. 514.

${ }^{32}$ Ibíd., p. 514. 
Expresamente menciona el caso de humos, agua y restos de piedras que ingresan al predio ajeno como ejemplos de inmisiones que a la época eran concebibles pero que no obsta a entenderla como mera descripción de supuestos y no como una enumeración taxativa. Además dispone que los otros propietarios podrán demandar a quien arrendó su propiedad para impedir que continúen las inmisiones, y a su vez, él podrá exigir del arrendatario productor de quesos lo pertinente por realizar actividades a las que no tenía derecho. Finalmente resulta relevante que el jurista señale el ejercicio del interdicto uti possidetis $^{33}$.

La teoría de las inmisiones no dice relación con la usurpación, despojo o tenencia de una cosa ajena. Simplemente es la imposibilidad de poder ejercer una posesión tranquila en un inmueble por alguna molestia causada en predio ajeno y de la cual no existe derecho para realizarla o tolerarla.

La teoría no es difícil de entender, de hecho, se presenta acorde a toda coherencia lógica. Sin embargo, el nivel de tolerancia que se debe atender en la materia es lo que presenta mayores problemas. En otras palabras, determinar la entidad de los fenómenos para que sean capaces de vulnerar el derecho de propiedad ajeno es lo que provoca mayor debate. En la mayoría de los casos los ruidos, olores, luces entre otros fenómenos producen algún grado de molestia al vecino pero son generalmente toleradas por ser inherentes a la cercanía de los inmuebles y propios de las actividades ordinarias que se desarrollan en ellas ${ }^{34}$.

Con la finalidad de determinar el grado de tolerancia en las relaciones de vecindad se han desarrollado, principalmente, las teorías de los actos de emulación, el criterio del uso normal y de la normal tolerancia y la necesidad social $^{35}$.

La teoría de los actos de emulación o la figura de aemulatio tiene su origen en los glosadores y comentaristas de la Edad Media para prohibir los actos que realiza el propietario en su propio inmueble con la única intención de causar un daño o molestia al vecino, especialmente en actos de edificación, construcción y aguas. En definitiva resulta importante en la emulación acreditar la intención maliciosa o dolosa (animus nocendi) de causar el mal sin que sus actos le reputen favor alguno al autor por sobre el daño mismo. Lo farragoso de su acreditación generó que se establecieran presunciones al respecto, siendo el autor material quien debía probar la utilidad. Para la sociedad medieval la figura de la emulación sirvió para impedir injusticias derivadas del ejercicio de la propiedad, siendo realmente un límite al dominio,

${ }^{33}$ Volveremos a este punto en el acápite V,5 ulterior.

${ }^{34}$ Claro Solar, L., Explicaciones, cit. (n. 10), VI, p. 353 n. 303.

${ }^{35}$ No existe entre los ordenamientos comparados un criterio común de aplicación de alguna de estas teorías para determinar el nivel óptimo de tolerancia. 
pero con el arribo de la época industrial los supuestos de pugnas vecinales se complejizaron al igual que el modelo social y económico. Este cambio supuso su merma como disciplina para resolver conflictos entre propietarios toda vez que las nuevas situaciones, tales como la inmisión, difícilmente podían ser resueltas mediante su aplicación ${ }^{36}$.

La teoría del uso normal se desarrolló en el siglo XIX en Alemania, primero por Spangenberg y luego por Ihering. El primero es considerado el iniciador de la teoría de las inmisiones porque fue el primero en extraer de Dig. 8,5,8,5 el principio general de no hacer en el predio propio aquello que inmite en el ajeno y, además, en afirmar que el nivel de tolerancia vecinal debe ser determinado por la envergadura de la molestia. En consecuencia, se debe tolerar aquello que implica un uso normal del inmueble y no así un uso anormal o irregular del mismo. Sin embargo, restringió la teoría únicamente a hechos inmisivos corpóreos que dañan la propiedad. Ihering complementó los postulados de Spangenberg al distinguir entre los efectos nocivos a la persona y a la propiedad. En ocasión de la primera se deberá estar al criterio de la valoración general de las personas (normal tolerancia) y en el segundo al aprovechamiento tradicional del inmueble (uso normal) con el fin de ofrecer cánones objetivos y facilitar la labor del juez. Ambas teorías son actualmente los criterios con mayor influencia en los ordenamientos jurídicos que tratan la materia ${ }^{37}$.

Finalmente, la teoría de la necesidad social es propuesta por el italiano Bonfante. El criterio se basa en el concepto de necesidad social como limite a la propiedad. Para depurar dicha noción señala que una actividad que revista el carácter de necesidad social debe ser necesaria, social, general y absoluta. Será necesaria si resulta imposible prohibirla legalmente porque supondría atentar contra la propia sociedad; social pues tiene por finalidad la coexistencia o convergencia de intereses colectivos; general por referirse a las necesidades recíprocas entre todos los interesados; y absoluta porque no existe una forma diversa de actuación. Bajo esta premisa, toda inmisión que sea producto de una actividad catalogada de necesidad social debe ser tolerada. En cuanto a la actividad industrial, solo deben ser toleradas las proyecciones negativas si la necesidad de su existencia es cotidiana y civil. En otras palabras, si una industria se ubica en una vecindad que ordinariamente

\footnotetext{
${ }^{36}$ Algarra Prats, E., cit. (n. 6), pp. 331-341; Díaz Romero, María del Rosario, La protección jurídico-civil de la propiedad frente a las inmisiones. Especial referencia a la acción negatoria (Madrid, Civitas, 2003), pp. 19-21; Navarro Mendizabal, I. A., cit. (n. 12), pp. 47-72; Macías Castillo, A., cit. (n. 8), pp. 68-72.

${ }^{37}$ Algarra Prats, E., cit. (n. 6), pp. 363-370.
} 
alberga este tipo de actividad podría ser considerada como una necesidad social y, por consiguiente, sus inmisiones toleradas ${ }^{38}$.

\section{Tratamiento comparado de las inmisiones.}

El presente acápite tiene por objeto exponer la aplicación de la teoría de las inmisiones en los principales ordenamientos jurídicos-civiles europeos y latinoamericanos. Exhibir el tratamiento jurídico de la disciplina ${ }^{39}$ en ordenamientos jurídicos foráneos es un punto de partida importante para convenir que su existencia y estudio no es azaroso ni antojadizo sino que responde a la consumación de una idea ampliamente divulgada y con trascendencia centenaria en el extranjero ${ }^{40}$.

Debemos distinguir entre los ordenamientos que cuentan con una regulación positiva expresa de las inmisiones, las que tienen una referencia directa a la materia y los que carecen totalmente de ella.

Los códigos civiles de reciente publicación, por regla general, expresamente consagran en materia de relaciones de vecindad normativa atingente a las inmisiones. La diferencia en su tratamiento radica precisamente en la época de su elaboración, siendo el fundamento dogmático de la propiedad y el estado de industrialización de las naciones la justificación de su expresa consagración. Los códigos clásicos o liberales concebían la propiedad como un derecho absoluto entre titulares de igual jerarquía que debía ser excepcionalmente limitado por la ley o reglamentos. La industria no había alcanzado gran desarrollo y las consecuencias nocivas eran desconocidas al igual que la densidad demográfica que revelarían las ciudades modernas. Evidencia de esto son los casos en que se regulan las limitaciones al dominio pues son ejemplos más atingentes a sociedades agrarias que industriales (arboles, pozos, letrinas, caballerizas, etc.). A contrario sensu, los cuerpos legales modernos tienen una concepción más flexible de la propiedad, pudiendo estar sujeta a otros intereses tanto públicos como privados. Asimismo, en su época el avance tecnológico permitía prever turbaciones a la propiedad distintas y de mayor significación que las históricamente tratadas. Tanto en

${ }^{38}$ Algarra Prats, E., cit. (n. 6), pp. 371-374; Navarro Mendizabal, I. A., cit. (n. 12), pp. 124-134.

${ }^{39}$ En concordancia con Algarra Prats, E., cit. (n. 6), p. 56, en este trabajo hablaremos de disciplina o teoría de las inmisiones y no propiamente de un Derecho pues carecemos de su regulación positiva en el Código Civil y, asimismo, de pronunciamientos doctrinales o jurisprudenciales que la avalen.

${ }^{40}$ No es nuestra intención el desarrollo histórico pormenorizado y los mecanismos de protección dispuestos para las inmisiones en el derecho comparado pues lo consideramos tangencial a lo que nos proponemos en este trabajo. Sin embargo, una exposición del reconocimiento de la materia es relevante porque ilustra al lector de la actual aplicación de la disciplina en otros ordenamientos y resalta la diferencia con el nuestro. 
los ordenamientos con regulación expresa, en los que existe una referencia directa o aquellos que carecen de normativa positiva, el fundamento de la disciplina en estudio es idéntica, a saber, la protección del propietario de un inmueble o de quien goza de él frente a las molestias proyectadas en su predio a causa de una actividad ajena, distinguiendo entre las inmisiones tolerables y las intolerables ${ }^{41}$.

Entre los ordenamientos que cuentan con normativa expresa en sus Códigos civiles mencionamos el artículo 906 alemán de $1959^{42}$, el artículo 844 italiano de $1942^{43}$, el artículo 1.346 portugués de $1966^{44}$, el artículo 684 suizo de $1907^{45}$, el artículo 364 austriaco de $1918^{46}$ y el artículo 1.003 griego

${ }^{41}$ Algarra Prats, E., cit. (n. 6), pp. 61-64.

${ }^{42} \mathrm{El}$ artículo $906 \mathrm{BGB}$ señala que: "el propietario de una finca no esta facultado a prohibir la penetración de gases, vapores, olores, humos, hollin, calor, ruidos, trepidaciones, e interferencias similares que emanen de otra finca en tanto que la interferencia no perjudique o no perjudique de forma no esencial al uso de la finca. / Lo mismo se aplica en tanto que se cause un perjuicio sustancial por el uso de otra finca en conformidad con las costumbres locales y no puede evitarse con medidas, cuya financiación puede esperarse de razonable de quienes la usan de este modo. Si, en virtud de esto, el propietario debe tolerar una interferencia, puede exigir de quien use la otra finca un acuerdo apropiado en dinero si por la interferencia, en conformidad con la costumbre local el uso del terreno o los ingresos de él, se ven perjudicados por encima del grado esperado. / La intrusión por un conducto especial no es permisible". Algarra Prats, E., cit. (n. 6), p. 66, expone que mediante actuación legislativa entró en vigor en 1994 el inciso primero del artículo previamente citado se modificó "en el sentido de considerar no esenciales aquellas inmisiones que no sobrepasen los valores o estándares máximos de emisión fijados por la Administración”.

${ }^{43}$ Dispone el artículo que: "El propietario de un fundo no puede impedir las inmisiones de humo o de calor, las exhalaciones, los ruidos, las sacudidas y propagaciones similares derivadas del fundo vecino, sino superan la normal tolerancia, teniendo en cuenta las condiciones del lugar.- En la aplicación de esta norma, la autoridad judicial debe equilibrar las exigencias de la producción con los derechos de la propiedad. Puede tener en cuenta la prioridad de un uso especifico".

${ }^{44} \mathrm{El}$ artículo 1.346 dispone que: "El propietario de un inmueble puede oponerse a la emisión de humo, hollin, gases, olores, calor o ruidos, asi como la producción de trepidaciones y a cualesquiera otros hechos semejantes, provenientes de predio vecino, siempre que tales hechos importen un perjuicio sustancial para el uso del inmueble o no resulten de la utilización normal del predio del que emana".

${ }^{45}$ Señala el artículo que: "El propietario está obligado, en el ejercicio de su derecho, especialmente en sus trabajos de explotación industrial, a abstenerse de todo exceso en detrimento de la propiedad vecina.- Están prohibidas en articular las emisiones de bumo o de hollin, las emanaciones molestas, los ruidos, las trepidaciones que tienen un efecto perjudicial y que exceden los limites de la tolerancia que se deben los vecinos, teniendo en cuenta el uso local, la situación y la naturaleza de los inmuebles". Traducción de PRATs, E., cit. (n. 6), p. 99.

${ }^{46} \mathrm{El}$ tenor del artículo es: "En general, el derecho de propiedad no puede ejercerse sino 
de $1940^{47}$. En Latinoamérica también existe regulación positiva en la materia, siendo el caso del artículo 2.618 argentino de $1971^{48}$, el artículo 961 peruano de $1852^{49}$, el artículo 1.277 brasilero de $2003^{50}$, el artículo 2.000 paraguayo

en la medida en que no cause ningún perjuicio a los derechos de un tercero y en tanto que no traspase los limites legales prescritos para el mantenimiento y el progreso del bien público.El propietario de un bien inmueble que sea perjudicado por las aguas residuales, el humo, el gas, el calor, los olores, el ruido, las sacudidas y otras cosas similares que provengan del fundo de un vecino puede prohibirlas, en cuanto excedan de la medida de los usos normales del lugary en tanto que perjudiquen gravemente una utilización de la propiedad conforme a su situación. En todas circunstancias, está prohibida una intervención directa, sin título jurídico". Traducción de Algarra Prats, E., cit. (n. 6), p. 102.

${ }^{47}$ Dispone el precepto que: "El propietario de un inmueble está obligado a tolerar la emisión de humo, hollin, exhalaciones, calor, ruido, sacudidas, $u$ otros actos similares procedentes de otro inmueble, en tanto que estos actos no perjudiquen esencialmente el uso de su propio inmueble, o que procedan de un uso ordinario para los inmuebles de la circunscripción del inmueble que causa el perjuicio". Traducción de Algarra Prats, E., cit. (n. 6), p. 106.

${ }^{48} \mathrm{El}$ artículo 2618 CCArg. dispone que: "Las molestias que ocasionen el humo, calor, olores, luminosidad, ruidos, vibraciones o daños similares por el ejercicio de actividades en inmuebles vecinos, no deben exceder la normal tolerancia teniendo en cuenta las condiciones del lugar y aunque mediare autorización administrativa para aquéllas.- Según las circunstancias del caso, los jueces pueden disponer la indemnización de los daños o la cesación de tales molestias.- En la aplicación de esta disposición el juez debe contemporizar las exigencias de la producción y el respeto debido al uso regular de la propiedad; asimismo tendrá en cuenta la prioridad en el uso.- El juicio se tramitará sumariamente". La actual redacción del artículo se debe a una modificación del año 2005.

${ }^{49}$ Dispone el artículo que el propietario, que en ejercicio de su derecho y especialmente en su trabajo de "explotación industrial, debe abstenerse de perjudicar las propiedades contiguas o vecinas, la seguridad, el sosiego y la salud de sus habitantes.- Están probibidos los humos, hollines, emanaciones, ruidos, trepidaciones y molestias análogas que excedan de la tolerancia que mutuamente se deben los vecinos en atención a las circunstancias".

${ }^{50}$ El precepto da cuenta que: "El propietario o poseedor de un inmueble tiene el derecho de hacer cesar las interferencias perjudiciales a la seguridad, la paz o la salud de los que lo habitan, provocadas por la utilización de propiedades vecinas.- Se probibe las interferencias considerando la naturaleza del uso, la ubicación del inmueble, de acuerdo con las normas que distribuyen las edificaciones en zonas y los limites de tolerancia normal de los habitantes de la vecindad". 
de $1987^{51}$ y el artículo 117 boliviano de $1975^{52}$.

En el ámbito de los ordenamientos privados que cuentan con una referencia directa de la disciplina de las inmisiones resulta importante el caso de España pues ha sido contundente la recepción de la teoría por parte de los tribunales y la doctrina nacional a pesar de carecer de norma expresa. La construcción dogmática se ha producido en virtud de los artículos $590^{53}$ y $1.902^{54} \mathrm{CCEsp}$. El primero da cuenta de la vertiente real de la disciplina (propiedad) y el segundo de la vertiente obligacional (responsabilidad extracontractual). Su interpretación y aplicación conjunta han permitido subsanar algunos de los problemas asociados a la falta de un precepto general tal como es la incorporación de nuevos fenómenos inmisivos. Sin perjuicio de otras regulaciones de las comunidades autónomas españolas, es importante destacar la Ley $\mathrm{N}^{\circ}$ 13/1990, de 9 de julio, denominada de la Acción negatoria,

${ }^{51}$ El artículo en comento señala que: "El propietario está obligado, en el ejercicio de su derecho, especialmente en los trabajos de explotación industrial, a abstenerse de todo exceso en detrimento de la propiedad de los vecinos. Quedan prohibidos en particular las emisiones de humo o de hollin, las emanaciones nocivas y molestas, los ruidos, las trepidaciones de efecto perjudicial y que excedan los limites de la tolerancia que se deben los vecinos en consideración al uso local, a la situación y a la naturaleza de los inmuebles. El propietario, inquilino o usufructuario de un predio tiene el derecho a impedir que el mal uso de la propiedad vecina pueda perjudicar la seguridad, el sosiego y la salud de los que habitan.Según la circunstancia del caso, el juez puede disponer la cesación de tales molestias y la indemnización de los daños, aunque mediare autorización administrativa".

${ }^{52}$ Leemos del precepto que: "I. El propietario debe evitar a los fundos vecinos las penetraciones de olores, humo, hollin, calor, luces de anuncio, trepidaciones o ruidos molestos u otras inmisiones, cuando exceden a las obligaciones ordinarias de vecindad. Se tendrá en cuenta la naturaleza de los lugares y la situación y destino de los inmuebles, conciliando en todo caso los derechos de propiedad con las necesidades del desarrollo. II. Esta disposición también se aplica a quienes poseen y a quienes detentan la cosa".

${ }^{53}$ Dispone el artículo: "Nadie podrá construir cerca de una pared ajena o medianera pozos, cloacas, acueductos, hornos, fraguas, chimeneas, establos, depósitos de materias corrosivas, artefactos que se muevan por el vapor, o fábricas que por si mismas o por sus productos sean peligrosas o nocivas, sin guardar las distancias prescritas por los reglamentos y usos del lugar, y sin ejecutar las obras de resguardo necesarias, con sujeción, en el modo, a las condiciones que los mismos reglamentos prescriban.- A falta de reglamentos se tomarán las precauciones que se juzguen necesarias, previo dictamen pericial, a fin de evitar todo daño a las heredades o edificios vecinos.

${ }^{54} \mathrm{El}$ precepto expresa que: "Igualmente responderán los propietarios de los daños causados. $1^{\circ}$. Por la explosión de máquinas que no hubiesen sido cuidadas con la debida diligencia, y la inflamación de sustancias explosivas que no estuviesen colocadas en lugar seguro y adecuado. $2^{\circ}$. Por los humos excesivos, que sean nocivos a las personas o a las propiedades. $3^{\circ}$. Por la caida de árboles colocados en sitios de tránsito, cuando no sea ocasionada por fuerza mayor. $4^{\circ}$. Por las emanaciones de cloacas o depósitos de materias infectantes, construidos sin las precauciones adecuadas al lugar en que estuviesen". 
inmisiones, servidumbres y relaciones de vecindad que regula expresamente en el derecho civil catalán las inmisiones y su mecanismo de protección, reflejando la trascendencia y el reconocimiento legislativo de la disciplina ${ }^{55}$.

En los ordenamientos latinoamericanos, esta referencia directa se hace presente en el Código Civil uruguayo ${ }^{56}$, ecuatoriano ${ }^{57}$, colombiano $^{58}$, nicaragüense $^{59}$, venezolano ${ }^{60}$ y salvadoreño ${ }^{61}$ pues si bien algunos contienen

${ }^{55}$ Algarra Prats, E., cit. (n. 6), pp. 149-168.

${ }^{56} \mathrm{El}$ artículo 612 CCUrug. dispone que: "Nadie puede construir cerca de una pared, sea o no medianera, pozo, letrina, caballeriza, horno, fogón, artefactos que se muevan por el vapor u otra fábrica de que pueda resultar daño a los edificios o heredades vecinas, sin guardar las distancias prescritas por los reglamentos generales o locales o sin construir las obras de resguardo necesarias y con sujeción, en el modo, a todas las condiciones que los mismos reglamentos previenen. Esta prohibición se extiende a los depósitos de pólvora, de materias búmedas o infectas y de todo lo que pueda dañar a la solidez, seguridad y salubridad de los edificios.- A falta de reglamentos generales o locales, se recurrirá a juicio pericial".

${ }^{57} \mathrm{El}$ artículo 912 CCEc. dispone que: "Si se trata de pozos, letrinas, caballerizas, chimeneas, hogares, fraguas, hornos u otras obras de que pueda resultar daño a los edificios o heredades vecinas, deberán observarse las reglas prescritas por las ordenanzas generales o locales, ora sea medianera o no la pared divisoria. Lo mismo se aplica a los depósitos de explosivos o combustión fácilmente inflamables, de materias húmedas o infectas, y de todo lo que puede dañar a la solidez, seguridad y salubridad de los edificios".

${ }^{58} \mathrm{El}$ artículo 914 CCCol. expresa que: "Si se trata de pozos, letrinas, caballerizas, chimeneas, hogares, fraguas, hornos u otras obras de que pueda resultar daño a los edificios o heredades vecinas, deberán observarse las reglas prescritas por las leyes de policía, ora sea medianera, o no, la pared divisoria. Lo mismo se aplica a los depósitos de pólvora, de materias humedas o infectas y de todo lo que pueda dañar a la solidez, seguridad y salubridad e los edificios".

${ }^{59} \mathrm{El}$ artículo 1.681 CCNic. señala que: "Nadie podrá construir cerca de una pared ajena o medianera, pozos escusados, cloacas, acueductos, hornos, fraguas, chimeneas, establos, depósitos de materias corrosivas, artefactos que se muevan por el vapor o fábricas que por si mismas o por sus productos sean peligrosas o nocivas, sin guardar las distancias prescritas por los reglamentos, o sin ejecutar las obras de resguardo necesarias con sujeción en el modo a las condiciones que los mismos reglamentos prescriban.- A falta de reglamentos se tomarán las precauciones que se juzguen necesarias, previo dictamen pericial, a fin de evitar todo daño a las heredades o edificios vecinos".

${ }^{60}$ Dispone la norma 701 CCVenez. que: "Nadie puede construir cerca de una pared ajena o medianera, aljibes, pozos, cloacas, letrinas, acueductos, hornos, fraguas, chimeneas, establos o caballerizas, depósitos de materias corrosivas, artefactos que se muevan por vapor u otra fuerza, fábricas destinadas a usos peligrosos o nocivos, ni poner establecimientos industriales o de cualquiera otra especie que causen ruido que exceda la medida de las comodidades ordinarias de la vecindad, sin guardar las distancias exigidas por los Reglamentos y usos del lugar, o sin construir las obras de resguardo necesarias, y sujetándose en el modo de construirlas a todas las condiciones que los mismos reglamentos ordenen. A falta de Reglamentos se ocurrirá al juicio de peritos".

${ }^{61} \mathrm{El}$ artículo $858 \mathrm{CCS}$ alv. señala que si se trata de pozos, letrinas, caballerizas, chimeneas, hogares, fraguas, hornos u otras obras de que pueda resultar daño a los edi- 
sutiles modificaciones al artículo 590 español, el fundamento es idéntico. Además, empero de carecer de norma expresa o de referencia respecto de la materia en la vertiente real, los Códigos Civiles de México ${ }^{62}$ y Honduras ${ }^{63}$ hacen responsable a los propietarios por humos y por otros fenómenos en sede de responsabilidad civil extracontractual al igual que el artículo 1.908 español.

Finalmente, existen los ordenamientos que a pesar de carecer de base legal positiva o a modo de una referencia directa han elaborado principalmente a través de la jurisprudencia de los tribunales de justicia y la doctrina un concepto que resuelve los problemas de inmisiones. En Francia, el Code Civil carece de toda norma que pudiera ser asociada a la materia en estudio ${ }^{64}$ por lo que la dogmatica elaboró una teoría de responsabilidad autónoma, con características específicas, que la distinguen a otros sistemas generales o particulares de responsabilidad previstos en el Code denominada "troubles de voisinage". Este criterio abarca supuestos mayores que la mera disciplina de las inmisiones por lo que es aplicable a todo tipo de conflictos vecinales ${ }^{65}$.

ficios o heredades vecinas, deberán observarse las reglas prescritas por las ordenanzas generales o locales, ora sea medianera o no la pared divisoria. Lo mismo se aplica a los depósitos de pólvora, de materias húmedas o infectas, y de todo lo que pueda dañar a la solidez, seguridad y salubridad de los edificios.

${ }^{62} \mathrm{El}$ artículo 2.241 dispone: "Igualmente responderán los propietarios de los daños causados: $1^{\circ}$.- Por la explosión de máquinas que no hubiesen sido cuidadas con la debida diligencia, y la inflamación de substancias explosivas que no estuviesen colocadas en lugar seguro y adecuado. $/ 2^{\circ}$.- Por los humos excesivos, que sean nocivos a las personas o a las propiedades. $/ 3^{\circ}$.- Por la caída de árboles colocados en sitios de tránsito cuando no sea ocasionada por fuerza mayor. $/ 4^{\circ}$.- Por las emanaciones de cloacas o depósitos de materias infectan tez, construidas sin las precauciones adecuadas al lugar en que estuviesen".

${ }^{63} \mathrm{El}$ artículo $1932 \mathrm{CCHond}$ señala: "Igualmente responderán los propietarios de los daños causados:/ I. Por la explosión de máquinas, o por la inflamación de substancias explosivas;/ II. Por el humo o gases que sean nocivos a las personas o a las propiedades;/ III. Por la caída de sus árboles, cuando no sea ocasionada por fuerza mayor; IV. Por las emanaciones de cloacas o depósitos de materias infectantes;/V. Por los depósitos de agua que humedezcan la pared del vecino o derramen sobre la propiedad de éste;/VI. Por el peso o movimiento de las máquinas, por las aglomeraciones de materias o animales nocivos a la salud o por cualquiera causa que sin derecho origine algún daño".

${ }^{64} \mathrm{El}$ artículo $674 \mathrm{CCFr}$. dispone: "Quien haga construir un pozo o una cloaca cerca de una pared medianera o no, quien desee construir una chimenea $u$ hogar, fragua, horno o fogón, adosar un establo o establecer contra esta pared un almacén de sal o depósito de materias corrosivas, estará obligado a dejar la distancia prescrita por las ordenanzas y costumbres particulares para estos objetos o hacer las obras prescritas por las mismas ordenanzas o costumbres para evitar dañar al vecino". Este precepto no es aplicable a la teoría porque se refiere sencillamente a las distancias y obras intermedias que se requieren para ciertas obras.

${ }^{65}$ Algarra Prats, E., cit. (n. 6), pp. 107-129. A estas páginas nos remitimos 


\section{Reflexiones en torno al concepto de inmisión en sentido amplio.}

La inmisión es un concepto extraño en nuestra doctrina. Incipientes han sido los esfuerzos por su desarrollo dogmático. Su definición y delimitación presenta dificultades que intentaremos soslayar en el presente acápite.

La inmisión en sentido amplio es la antítesis de emisión. La Real Academia Española la define como "infusión o inspiración" 66 y a la emisión como "acción y efecto de emitir", que a su vez es "arrojar, exhalar o echar hacia fuera algo" ${ }^{37}$. De los conceptos previos solo podemos decantar que mientras la emisión es algo que se expulsa la inmisión es algo que se recibe. Hasta este punto diremos que se trata de un mismo algo pero diferenciado por el lugar de producción y de recepción. Son los efectos de un mismo hecho pero observado desde punto de vistas disímiles.

De la definición de emisión también se aprecia que el origen de ese algo que potencialmente puede constituir una inmisión debe ser originado en una acción. Los verbos arrojar, exhalar y echar evidencian una actuación humana por lo que una omisión o evento natural no da lugar a una inmisión ${ }^{68}$.

Además la turbación no guarda vínculo con el propósito que la motiva. Así pues la exigencia para que un hecho sea considerado emisión es que sea fruto de una acción humana sin mediar intencionalidad. A su vez, si la inmisión fue producto de una intención positiva de causarla o fue sencillamente una consecuencia indeseada no es factor determinante de la existencia del hecho ${ }^{69}$.

para la fundamentación dogmática del carácter autónomo de la responsabilidad por "troubles de voisinaje" como al régimen especial de las nuisances.

${ }^{66}$ Diccionario de la Lengua Española (22a edición, 2001), II p. 1.279. Navarro Mendizabal, I. A., cit. (n. 12), p. 30 también parte de esta base para introducir la materia.

${ }^{67}$ Diccionario, cit., I, pp. 882-883.

${ }^{68} \mathrm{La}$ omisión como evento que produzca una inmisión puede ser objeto de análisis. Tal vez algún caso de laboratorio podría encontrar en ella un punto de partida pero a nuestro juicio no es practicable. En este sentido compartimos con MACías CASTILlo, A., cit. (n. 8), pp. 266-267, que la falta de acción no produce inmisión, pero la omisión no debe ser confundida con la falta de diligencia para impedir que una actividad humana lo produzca. Expone el autor que "el humo, los olores nauseabundos, los ruidos, las vibraciones,... que invaden una vivienda, suponen la existencia de una acción, la que los inmite: el horno, la industria o la maquinaria que se pone en marcha para producirlos. Esto es una acción del hombre. El que no se adopten-omisión-las medidas oportunas para evitar el humo, los olores o el ruido se propaguen en forma perjudicial o dañosa hasta la vivienda no significa que el daño sea causado en razón de dicha omisión. El daño es causado por la acción de inmitir. La omisión, en su caso, implicará la existencia de culpa, puedes debiendo evitarse los daños previsibles y evitables, no se evitaron".

${ }^{69}$ En el mismo sentido Cabanillas SánChez, Antonio, La reparación de los daños al medio ambiente (Pamplona, Editorial Aranzadi, 1996), p. 55. 
Es legítimo cuestionar si la inmisión debe interesar al Derecho. Solo los hechos jurídicos son relevantes en desmedro de los simples hechos. Debemos recordar que "se afirma en doctrina que un hecho está dotado de relevancia jurídica cuando su acaecimiento permite cambiar una realidad preexistente, creándose nuevas situaciones que van a tener distinta clasificación jurídica"70 $y$, que en consecuencia, producirá efectos jurídicos. Para que el hecho los produzca debe estar previsto en la norma positiva lo que en ocasión de las inmisiones estimamos que sí ocurre ${ }^{71}$.

Asimismo, la inmisión es un hecho jurídico complejo, positivo y potencialmente impeditivo $^{72}$. Es complejo toda vez que requiere más de un hecho para que acaezca, a saber, la producción de un elemento en una finca ajena y que penetre en otro inmueble. Es positivo porque requiere que el elemento ingrese a predio ajeno y es impeditivo, siempre y cuando sea intolerable, porque su existencia impide que se puedan ejercer establemente la posesión de un inmueble o los derechos reales constituidos sobre él. Por lo tanto la inmisión sí es un hecho jurídicamente relevante que interesa al Derecho.

Desde un punto de vista privado, concierne la inmisión cuando, entre otros factores, la turbación se proyecta y molesta en la esfera jurídica de un inmueble distinto al que la produce. Sería improcedente hablar de inmisión cuando es el propio predio productor el que sufre los efectos nocivos. De lo contrario sería obviar el principio "nemo auditur qui propriam turpitúdinem alegans" al considerar que aquel que produce la inmisión puede verse perjudicado por su propio dolo o negligencia. Asimismo no se dan los supuestos de inmisiones porque la actividad no es ajena (la producción es propia) y no penetra en inmueble vecino (produce los efectos en el mismo lugar). Tan solo es la proyección de una emisión en campo propio. En la medida que no sea contrario a la normativa vigente no significa un acto ilegítimo.

La inmisión, en sentido general, es un concepto que no dice relación con la intencionalidad del emisor ni con su licitud o ilicitud. Se presenta como un hecho, un algo que penetra en deslindes ajenos. No es un concepto que a priori pueda ser catalogado de forma positiva o negativa. Infusión o inspiración no tienen ningún tipo de connotación asociada. De hecho, la inmisión

${ }^{70}$ VIAL DEL Río, Víctor, Teoría general del acto jurídico (4a edición, Santiago Ediciones Universidad Católica de Chile, 2000), p. 21.

${ }^{71}$ Nos remitimos a lo que expondremos en el acápite III,6 ulterior.

${ }^{72}$ Vial del Río, V., cit. (n. 70), pp. 19-24. 
en sentido amplio es un hecho puro y simple, carente de carga valorativa inicial ${ }^{73}$ pues es un concepto con "neutralidad axiológica" ${ }^{4}$.

Sin embargo, en el sentido jurídico-técnico del concepto, la inmisión debe presentar ciertos caracteres que permitan reputarlo como un hecho molesto e intolerable para el poseedor o las personas que tienen derechos reales constituidos en el inmueble. Solo algunas invasiones a la propiedad ajena son susceptibles de ser considerados hechos que permiten el despliegue de mecanismos de protección que el ordenamiento privado dispone por inmisiones.

\section{Clasificaciones de la inmisión y esbozo de una definición jurídico- técnica.}

La inmisión en sentido amplio o general es algo que penetra en predio ajeno. Constituye entonces un agravio contra el dueño del inmueble afectado quien no está sujeto a la obligación de sufrir tal turbación.

El principio general que informa la teoría de las inmisiones es que se puede hacer en lo propio todo lo que no proyecte consecuencias negativas a los inmuebles vecinos. En consecuencia, no toda intervención en la propiedad ajena supone una inmisión en términos jurídicos. Es un concepto técnico y con características propias que lo distinguen de otras invasiones. La determinación de estos caracteres permitirá reconocer los fenómenos atribuibles al concepto técnico de inmisión y en ocasión de los cuales la teoría debe ser aplicada. Para esto efectos, destacamos la clasificación de Navarro quien hace un énfasis en su utilidad práctica por sobre un estricto enunciado taxativo de casos $^{75}$.

${ }^{73}$ Hacemos presente que el punto no es pacífico en la doctrina extranjera. En MACías Castillo, A., cit. (n. 8), pp. 124-125, se critica la Ley $N^{\circ} 13 / 1990$, de 9 de julio, De la acción negatoria, inmisiones, servidumbres y relaciones de vecindad de Cataluña (LANISRV) pues expone que toda inmisión supone ilegitimidad mencionando las fuentes romanas para apoyar su tesis. Asimismo, estima que la expresión que la ley utiliza de inmisiones dolosas o culposas no procede toda vez que la inmisión no debe responder a un elemento subjetivo sino en función de un nivel de molestia determinados para el caso concreto. La intención o negligencia en la actuación debe ser estudiado con posterioridad para determinar las consecuencias del hecho. Nos parece que la distinción entre el concepto de inmisión genérico y uno técnico es vital para salvar la dificultad. Éste no necesariamente será ilegítimo pero aquél sí lo será. Por otro lado, compartimos con el autor que el dolo o culpa del emitente no condiciona la existencia de la inmisión pues muchas veces las proyecciones no son siquiera vislumbradas por el autor en el ejercicio de un derecho de propiedad.

${ }^{74}$ Navarro Mendizabal, I. A., cit. (n. 12), p. 33. El autor opina que la definición de inmisión debe ser amplia, abarcando todos los supuestos y totalmente neutra por tratarse de una realidad fáctica susceptible de calificación jurídica.

${ }^{75}$ Ibíd., pp. 33-40. Sin embargo no compartimos la clasificación de inmisiones na- 
a) Inmisión directa e indirecta. Son inmisiones directas "[...] todos los actos de ejercicio del derecho de propiedad sobre un fundo que impliquen una invasión directa en la finca vecina" ${ }^{\text {76 }}$ pues violenta el carácter exclusivo de la propiedad inmitida. Así, lanzar balones a la casa colindante o acumular la tierra resultante de una excavación en el predio ajeno constituyen un "facere in alieno". Implica un ataque directo a la propiedad ajena y por lo

turales y artificiales pues como hemos señalado el concepto de inmisión supone una actuación humana. De no mediar acción por parte de una persona, lo que se proyecta a un predio ajeno no puede ser catalogado de inmisión. Será un hecho de la naturaleza que no corresponde al derecho tutelar. Un claro ejemplo lo constituye la radiación solar. El emisor de dicha energía es una estrella ajena al hombre. Sin embargo la radiación penetra en las distintas propiedades. A este supuesto no se le puede considerar más que un hecho natural y nunca una inmisión. Primero porque no se origina en un predio vecino por lo que escapa a las relaciones de vecindad y segundo puesto que no interviene una acción humana. Otro ejemplo, esta vez normativo, se encuentra consagrado en el artículo 833 del Código Civil. Se le llama servidumbre natural a la carga del predio inferior a recibir las aguas que desciendan del predio superior naturalmente, es decir, sin que la mano del hombre contribuya a ello. No es inmisión en virtud que falta de acción humana. Estimamos que haber denominado este supuesto como una servidumbre natural que limita los derechos de propiedad en las relaciones de vecindad es digno de admiración toda vez que su redacción es del siglo XIX. NAVArro Mendizabal, I. A., cit. (n. 12), p. 34 en cambio postula que la norma en comento constituye una inmisión natural y no una servidumbre. Sin embargo dejamos de manifiesto que a pesar de discrepar en este punto con el autor, ambos concluimos que no puede ser objeto de tutela. Tampoco compartimos la clasificación de inmisión moral o ideal. Dicha clasificación atiende a la desvalorización económica de un inmueble ante circunstancias ajenas al predio. La denominación moral, expone el autor, en Navarro Mendizabal, I. A., cit. (n. 12), pp. 38-39, responde a que es una inmisión social en que efectivamente no se proyecta nada en la propiedad, sino que con posterioridad a un análisis de factores económicos o estéticos se asemejaría a una inmisión. Pensemos en la construcción de un edificio frente a nuestra ventana que nos impide continuar disfrutando de la vista al mar, la destrucción de un agradable parque aledaño a nuestro hogar o la utilización de la casa vecina para desarrollar actividad que pugnan con las buenas costumbres. En todos estos casos la propiedad perderá valor económico. A contrario sensu, la estación de un metro subterráneo que se construye en la proximidad de nuestra propiedad o ante el evento que se autorice la modificación del uso del terreno de una propiedad rural para fines industriales o inmobiliarios probablemente produzcan el aprecio del inmueble. A nuestro juicio esto no es una clasificación idónea de inmisión porque sencillamente nada penetra en el predio. Recordemos que la infusión en propiedad ajena es un hecho fáctico que en estos casos no se presenta. Además, las facultades del dominio se restringen a los contornos de la propiedad siendo improcedente pretender intervenir en situaciones externas sin que medie autorización legal o una servidumbre. Por último, la valorización o depreciación de una propiedad tiene que ver con factores ajenos a los jurídicos lo que en estricto rigor no supone afección al goce de una propiedad.

${ }^{76}$ Egea Fernández, Joan, Acción negatoria, inmisiones y defensa de la propiedad (Madrid, Marcial Pons, 1994), p. 73. 
tanto el autor será responsable de un delito o cuasidelito en la medida que se acredite su dolo o culpa.

Las inmisiones indirectas constituyen un acto de invasión cuando las consecuencias del ejercicio de las facultades del dominio en lo propio se propagan hasta lo suyo. Son un "facere in suo" pues el origen de la injerencia no se encuentra en el predio afectado y la vulneración del derecho ajeno se produce cuando la propagación de los efectos de una actividad foránea ingresan a otra propiedad. Son ejemplos los olores, humos, ruidos, humedades, calores, radiaciones entre otros.

Navarro expone que el criterio para utilizar esta clasificación también ha sido el "momento en el que desaparece el actuar humano" 77 . Será directa en la medida que el actor inmitente genere los mecanismos idóneos para que un elemento penetre en finca ajena. No dice relación con el elemento subjetivo del actor sino con los medios empleados, pudiendo ser artificiales o intelectuales. Serán artificiales todos aquellos mecanismos empleados que conlleven necesariamente una inmisión y siempre que las fuerzas naturales, ajenas a la manipulación humana, no intervengan en el proceso. Así, canalizar los desechos de una fábrica hasta el deslinde de la propiedad para que caigan en la contigua es una inmisión directa y artificial. A contrario sensu, canalizar los desechos hasta una colina cuya pendiente cruza el lindero constituye una inmisión directa e intelectual toda vez que se aprovecha de las características del terreno para generar la turbación.

Asimismo, hacemos presente que los árboles cuyas ramas o raíces se extienden o penetran en predio ajeno (artículo 942 CC.) son casos de inmisión directa pues es la misma cosa que ingresa al inmueble sin requerimiento de fuerza o medios naturales ajenos.

La inmisión indirecta "supone una propagación de cuerpos o actividades de un fundo a otro" ${ }^{78}$. El medio través del cual se proyecta la inmisión en la finca ajena no es obra humana sino producto de elementos abióticos como el caso de las cenizas que caen el predio vecino a través del viento.

Para la disciplina en estudio es solamente trascendente la inmisión indirecta. Un ataque directo supone el dolo del autor y conlleva la aplicación de la responsabilidad aquiliana. En el caso de los árboles se observará lo dispuesto en el Código Civil. La inmisión indirecta generalmente no presupone una intención positiva de causar daño o malestar al vecino. Muchas de las veces serán proyecciones ignoradas por el autor o producto de actividades autorizadas por la administración. Además, la turbación debe proyectarse a

\footnotetext{
${ }^{77}$ Navarro Mendizabal, I. A., cit. (n. 12), p. 35.

${ }^{78}$ Ibíd., p. 35.
} 
través de medios naturales, ajenos a la voluntad humana, lo que es difícil de concebir en una invasión directa.

b) Inmisión material e in material. Sabemos que una primera clasificación de la inmisión en términos estrictos es que debe ser indirecta. Pero toca determinar el tipo de elementos que pueden consistir en una inmisión en sentido técnica. Lo importante será que algo penetre en la esfera jurídica del inmueble vecino ${ }^{79}$. Dichos elementos no podrán ser meramente espirituales o morales porque la molestia debe ser materialmente acreditable.

El hollín y las cenizas son evidentes ejemplos de cosas materiales que se proyectan en espacios ajenos a través de medios naturales. Sin embargo los ruidos, olores, humos, gases, calores, vibraciones u otras energías también son supuestos de inmisiones pero que presentan dificultades para ser clasificadas como una inmisión material o inmaterial ${ }^{80}$.

En nuestro ordenamiento es preciso observar el artículo 565 CC. para efectos de madurar un concepto de materialidad de las inmisiones. Señala el precepto que los bienes pueden ser cosas corporales o incorporales, siendo éstas las que tienen un ser real percibible por los sentidos y aquéllas los meros derechos ${ }^{81}$.

${ }^{79}$ Constantemente se ha hecho presente que esto respondería a una nueva clasificación, diferenciando entre inmisiones positivas o negativas. Las primeras dicen relación con que algo efectivamente penetre o se proyecte en predio ajeno que prive del uso o goce de la propiedad vecina. A contrario sensu, la inmisión negativa consistiría en palabras de Cabanillas Sánchez, A., cit. (n. 69), p. 57 en impedir “[...] la entrada de algo, como por ejemplo, si se priva al vecino del sol, del aire, o del agua, sin perjuicio de la acción que corresponda para que cede esta conducta abusiva [...]”. En estricto sentido no penetra nada sino que se priva al vecino de una ventaja o derecho. Estimamos que las fuentes históricas y la propia definición de inmisión no avalan que una privación se considere parte integrante del concepto. Por lo tanto, creemos que dicha clasificación resulta forzada y no contribuye en demasía al despeje de un concepto técnico. Sin embargo es común encontrar en la doctrina comparada que se utilice como una válida clasificación. En este sentido Díaz Romero, M. del R., cit. (n. 36), p. 33; y Algarra Prats, E., cit. (n. 6), pp. 282-288.

${ }^{80}$ En palabras de Navarro Mendizabal, I. A., cit. (n. 12), p. 37, "la distinción entre inmisiones materiales e inmateriales ha supuesto muchas discusiones doctrinales, por cuanto con ella se ha pretendido excluir las inmateriales del término inmisión, so pretexto de un dudoso, o no siempre claro, deber de soportarlas. Se razona que una inmisión inmaterial al no suponer la introducción de nada material, no es siquiera una introducción y por ende tampoco inmisión”. Otros como EgEa Fernández, J., cit. (n. 76), p. 76; y Cabanillas Sánchez, A., cit. (n. 69), p. 57-58, radica la distinción en que la materialidad de la clasificación no se debe sujetar a la corporeidad de los elementos sino a la posibilidad de medirlos físicamente.

${ }^{81}$ Entendemos que para estos efectos como sinónimos los conceptos corporalidad y materialidad. 
Es importante distinguir si las fuerzas o energías, carentes de corporeidad visible, pueden ser consideradas cosas materiales o no. El Código Civil no define los conceptos de cosa y bien. Generalmente se dice que existe una relación de género y especie entre ellos. Mientras la cosa es todo lo que ocupa un lugar en el espacio, el bien es solo aquello que prestando utilidad al hombre es susceptible de apropiación. La evolución de la ciencia y la tecnología han permitido un mejor acercamiento al asunto.

Las energías pueden ser explicadas en función de ondas que se propagan a través de diversos medios. En consecuencia, a pesar de carecer de materialidad, la luz, sonido, gas, ruido y la energía o fuerzas en general ocupan un lugar en el espacio por lo que jurídicamente deben considerarse cosas. Son entidades carentes de materialidad mas no inexistentes.

Habiendo despejado esta primera cuestión, es menester determinar si esas cosas pueden ser denominadas jurídicamente bienes. Para ello, la cosa debe cumplir con dos requisitos: reputar una utilidad al hombre y que pueda ser apropiada. Son requisitos copulativos para que la energía sea jurídicamente un bien, permitiendo su clasificación en corporal o incorporal conforme al artículo 565 CC.

Más que si el ruido, gas o luz, entre otros, son útiles al hombre la apropiación es lo que a nuestro juicio representa una mayor dificultad. Los avances tecnológicos promueven nuevos mecanismos de captura y control de energías que tienden al beneficio humano. Es por esto que las energías deben ser consideradas cosas inmateriales, a pesar de no ser derechos ${ }^{82}$, y en la medida que el avance científico permita su apropiación en pos de la utilidad humana, deberán ser clasificadas jurídicamente como cosas corporales o materiales, y particularmente, muebles ${ }^{83}$.

A mayor abundamiento, son las cosas incorporales que para efectos de las inmisiones suponen los hechos más cotidianos de molestia. Las cosas corporales que ingresan en suelo ajeno, tal como basura, piedras, entre otros, son eventos más atribuibles a la teoría del abuso del derecho que a la inmisión.

Los ordenamientos jurídicos que regulan positivamente las inmisiones en

${ }^{82}$ El tema no es pacífico ya que Amunátegui Perelló, C. F., No siendo contra derecho ajeno, cit. (n. 28), p. 516 manifiesta que "[...] el ruido no es un derecho, por lo que caería perfectamente dentro de las cosas corporales y ha de ser tratado como tal respecto a las inmisiones".

${ }^{83}$ Peñailillo Arévalo, D., cit. (n. 11), pp. 14-17, n. 4. Para el problema de las energías o fuerzas naturales y, particularmente respecto de la necesidad de apropiación de las fuerzas, ver Alessandri Rodríguez, Arturo, Curso de derecho civil. Los bienes $y$ los derechos reales ( $3^{a}$ edición, Santiago, Editorial Nascimento S.A., 1974), pp. 11-13 n. 8; También EgaÑA, Manuel Simón, Bienes y derechos reales (Caracas, Editorial Criterio, 1964), pp. 71-72. 
sus Códigos Civiles ${ }^{84}$ tienden a exponer supuestos inmateriales tales como los gases, vapores, olores, humos, calores, ruidos, trepidaciones, exhalaciones, sacudidas y luminosidades. Los únicos fenómenos netamente corporales que se regulan son el hollín por regla general; el agua residual y ceniza en particular. En efecto, esta clasificación atiende más al hecho que materialmente se proyecte un fenómeno en un inmueble ajeno que a su corporalidad.

Con el tiempo y el desarrollo de nuevas tecnologías se incrementarán los fenómenos que pueden dar lugar a una inmisión pero independiente de su corporeidad, para efectos que sean considerados una inmisión en sentido estricto, tendrán que materialmente proyectarse en un predio vecino por medios naturales. La disciplina jurídica resulta trascendente para determinar la tolerabilidad de la inmisión, relegando a otras ciencias la determinación de su materialidad. Solo en la medida que la entidad del hecho sobrepase los límites para la convivencia y se puedan reputar de molesto o directamente dañino es que podrá ser denominado como una inmisión pues impide el libre goce de un inmueble ${ }^{85}$.

c) Inmisión temporal o permanente. Debemos clasificar las inmisiones por su perpetuación. Dependiendo de la prolongación en el tiempo de una inmisión se podrá denominar temporal o permanente. La dificultad recae en definir el momento preciso en que ésta pasa a ser aquella ${ }^{86}$.

Una injerencia aislada no produce en el afectado el ánimo de hacerla cesar toda vez que al ejercer el derecho ya no existirá molestia que eliminar y la solicitud será fácticamente extemporánea. A contrario sensu, cuando una inmisión se prolongue constante o continuamente en el tiempo la pretensión del afectado estará orientada a obtener su cesación sin perjuicio de la respectiva indemnización que proceda. En el primer supuesto se podrá solicitar una indemnización por el hecho de haber sufrido perjuicio en un momento específico pero en caso que sea permanente en el tiempo, la pretensión se tornará hacia el término de la molestia e impedir su ulterior acaecimiento. La temporalidad de la inmisión tendrá relevancia en la causa de pedir y el petitum del libelo.

d) Definición. La inmisión es un concepto que subyace oculto para doctrina nacional y cuyo valor no ha sido recogido por nuestra jurisprudencia. Su estudio probablemente abrirá la puerta a un nuevo punto de vista en la

\footnotetext{
${ }^{84}$ Remitimos a lo expuesto en el acápite III, 2 anterior.

${ }^{85}$ En este punto nos remitimos a las teorías expuestas en el acápite III,1 anterior.

${ }^{86}$ Navarro Mendizabal, I. A., cit. (n. 12), p. 39, se pregunta “'ja partir de qué minuto de inmisión continua podemos calificarla de permanente sin temor a equivocarnos? Por ello solo se puede señalar que las inmisiones que se prolonguen largamente en el tiempo serán consideradas permanentes, mientras que las que no lo hagan tanto serán temporales".
} 
protección de la propiedad. El término en sentido amplio es axiológicamente neutro pero en una faceta estricta se colma de valor pues es la premisa sobre la que opera la teoría de las inmisiones.

Intentar esbozar una definición técnica en este campo no resulta tarea sencilla pues jamás hará justicia a la complejidad de la casuística. Como hemos dicho, los supuestos de inmisiones hace un siglo eran más acotados que los actuales y probablemente en un siglo más devendrán otros nuevos. El concepto debe ser amplio, capaz de abarcar todos los imponderables sin perjuicio de ofrecer certeza y vigencia atemporal.

En definitiva entendemos que la inmisión en sentido técnico-jurídico es la invasión material de uno o más fenómenos físicos que se proyectan indirectamente a través de medios naturales ajenos la voluntad humana en un predio distinto al de su producción por un período de tiempo prolongado y que impide el tranquilo uso y goce del inmueble afectado por parte del poseedor o de quien tenga un derecho real constituido en él.

\section{El ruido como fenómeno inmisivo.}

Las trepidaciones provocadas por el sonido son un presupuesto de inmisión. La penetración de un ruido en lugar ajeno es una realidad con la que debemos convivir diariamente y que provoca graves e indeseadas molestias entre vecinos ${ }^{87}$. Es importante destacar que el ruido como fenómeno inmi-

${ }^{87}$ No es infrecuente observar las denuncias públicas que diversas personas realizan a causa del ruido generado por sus vecinos. Tal es el caso de quienes acusan las molestias acústicas producto de los eventos en pubs y en el Parque Bicentenario en la comuna de Vitacura; una fiesta en el balneario de Papudo que impidió el descanso de quien vacacionaba; los ruidos de las ferias libres en La Florida; discoteques en las comunas de Lo Prado y Lo Espejo; un inmueble abandonado en Talca que ha sido apropiado por ruidosos antisociales; el incesante sonar de una alarma de supermercado en Santiago; los ruidos de una construcción y ceremonias de la Escuela de Carabineros en la comuna de Providencia; las fiestas organizadas por una junta vecinal en predio colindante ubicada en la comuna de Peñalolen; el alto volumen de la música proveniente de un recinto polideportivo y otros eventos en los jardines de un inmueble municipal en la comuna de Nuñoa. Véanse: El Mercurio (Santiago), 8 de diciembre de 2012, C, p. 34: "La frágil coexistencia entre vecinos, locales comerciales y constructoras"; El Mercurio (Santiago), 20 de noviembre de 2012, C, p. 19: "Alega que el ruido incesante de una fiesta lo obligó a regresar a Santiago"; El Mercurio (Santiago), 3 de enero de 2013, C, p. 23: "Vecina está molesta con los ruidos producidos en la Escuela de Carabineros" y "Residentes de Av. Lo Ovalle no duermen por bulla y peleas que se producen en discoteque"; El Mercurio (Santiago), 2 de enero de 2013, C, p. 21: "Ruidosa alarma de supermercado no deja dormir de noche"; El Mercurio (Santiago), 25 de enero de 2013, C, p. 19: "El caso de Sergio Marchant: Le molesta que la sede vecinal se haya convertido en una especie de discoteque"; El Mercurio (Santiago), 23 de enero de 2013, C, p. 15: "Vecinos molestos con evento"; El Mercurio (Santiago), 25 de febrero de 2013, 
sivo ostenta características inherentes que lo distinguen de otros elementos pues "a diferencia de otros contaminantes, el ruido no deja residuos, no tiene sabor, olor, textura o color, por lo que se suele decir que el ruido es un contaminante invisible. Su radio de acción o de impacto se encuentra limitado a las características de la fuente que lo genera y del entorno donde se propaga" ${ }^{88}$.

Recordemos que el término inmisión en sentido genérico es axiológicamente neutro, y en consecuencia, que un sonido originado por una actividad humana sea percibido en otra propiedad no supone per se un malestar. Al contrario, pensemos en sonidos que a la mayoría nos agradan e incluso son fuente de admiración. El trinar de las aves, el sonido de una fuente de agua o el oleaje del mar son hechos que disfrutamos. Sin embargo, pareciera que actualmente el concepto que mejor explica el vínculo con una actividad sonora es el tedio y no precisamente el deleite.

La Real Academia Española define sonido como una "sensación producida en el órgano del oído por el movimiento vibratorio de los cuerpos, transmitido por un medio elástico, como el aire" ${ }^{19}$. La sensación atenderá a factores subjetivos tales como la intensidad, tipo, combinación, frecuencia entre otros. Sin embargo el sonido es un hecho fáctico cuya existencia se explica en términos físicos y no jurídicos.

En el vacío una fuente emisora no producirá ningún sonido. Es necesario que exista un medio que permita que las ondas sonoras puedan desplazarse hasta el oído para su audición. El medio por excelencia del sonido es el aire sin perjuicio que también puede ser a través del agua, tierra u otros ${ }^{90}$.

C, p. 19: "Bullicio que generan actividades deportivas y recreativas molesta a vecina de Nuñoa"; El Mercurio (Santiago), 18 de febrero de 2013, C, p. 15 "Molesto con ruido que organiza la municipalidad”. También es relevante que en la Región Metropolitana exista una marcada concentración en la oferta de locales de diversión tales como centros de juego, teatros, cines, pubs, discoteques y restaurantes que incide directamente en los ruidos molestos que en esos sectores de la capital se perciben. En este sentido, de un total de 34 comunas, Vitacura, Las Condes, Providencia y Santiago congregan el 54.5\% de la oferta de diversión. Véase: El Mercurio (Santiago), 8 de diciembre de 2012, C, p. 22: "En sólo cuatro comunas de concentran más de la mitad de la oferta de diversión de Santiago".

${ }^{88}$ PONCE, Marcela, Informe del estado del medio ambiente 2011 (Santiago, A. Molina S. A., 2012), p. 169.

${ }^{89}$ Diccionario de la Lengua Española (22a edición, 2001), II, p. 2.091.

${ }^{90} \mathrm{Grau}$, Juan, Contaminación del aire y ruido. Análisis y soluciones de la contaminación atmosférica, acústica y radioactiva (Santiago, Ediciones OIKOS Ltda., 1981), p. 156. El autor explica que "cuando la fuente emisora de sonido vibra, esta vibración actúa sobre el aire comprimiéndolo y descomprimiéndolo. Esta vibración produce bandas densas y bandas livianas, y al igual que las ondas de la superficie de un estanque, cuando se tira en ella una piedra, se desprenden hacia afuera las ondulaciones que transportan 
Como máxima diremos que todo ruido es sonido pero no todo sonido es ruido. Existe una relación de género a especie en los conceptos. Ruido es definido por la Real Academia Española como un "sonido inarticulado, por lo general desagradable" ${ }^{\prime 1}$. Por lo tanto inmisión sonora intolerable es el movimiento vibratorio de un cuerpo, producido en predio ajeno que se proyecta por medios elásticos y que el poseedor de un inmueble vecino percibe como molesto ${ }^{92}$. El absurdo de este tipo de inmisión es que pasa a configurar un criterio de normalidad en la actualidad. Preocupa la pasividad de la comunidad ante tan indeseado enemigo que paulatinamente ha devenido en una consentida externalidad social ${ }^{93}$.

El sonido, y en particular el ruido, es un tema de suma relevancia toda vez que se presenta como un incansable compañero del ser humano durante su concepción, nacimiento y toda su existencia. Los ruidos molestos tienen diversas fuentes ${ }^{94}$ pero afecta exclusivamente al hombre. Dicho de otro modo, no afecta directamente al medio ambiente y sus componentes sino que únicamente al ser humano. Es por esto que el ruido es un factor de distorsión ecológico pues impide al hombre habitar un entorno tranquilo95.

Es importante regular el ruido como fenómeno inmisivo pues sus efectos

el sonido y a eso se llama ondas sonoras, que viajan por el aire a una velocidad de 1.200 $\mathrm{km}$./hora o 334 metros por segundo [...] La intensidad del sonido es la fuerza o presión que ejerce la comprensión en el aire u otro medio. Comparada con otras energías la intensidad del sonido es muy pequeña. El tímpano recibe esta fuerza de compresión y descompresión y lo transmite para ser interpretado por el cerebro [...]. El decibel es una unidad internacional que mide la intensidad del sonido".

${ }^{91}$ Diccionario de la Lengua Española (22a edición, 2001), II p. 1996.

${ }^{92}$ Lo que se mueve y en definitiva es lo que constituye la inmisión sonora no es el medio elástico sino las ondas que lo utiliza para propagarse. Véase: MARTín Mateo, Ramón, Tratado de Derecho ambiental (Madrid, Editorial Trivium S.A., 1992), II, p. 606.

${ }^{93}$ Macías Castillo, A., cit. (n. 8), p. 160, pone de manifiesto este fenómeno: "Vivimos en una sociedad cada vez más ruidosa, que no se preocupa por procurar el descanso y la tranquilidad de las personas, lo que sería un verdadero logro característico de una sociedad moderna y avanzada. Pero más bien sucede todo lo contrario. El tráfico crece imparablemente, los locales de ocio y esparcimiento son casi siempre lugares asociados con el ruido inopinado, por doquier suenan estridentes alarmas o irrespetuosos timbres de teléfonos móviles, que como si de la moderna peste del siglo XXI se tratase, suenan en los lugares y momentos más inesperados. $\mathrm{Y}$ todos asistimos a este fenómeno con indiferencia y, prácticamente, sin ninguna capacidad de asombro".

${ }^{94}$ Destacamos el aporte que constituye el trabajo de GrAU, J., cit. (n. 90), pp. 162$180 \mathrm{~m}$ en relación con la historia del ruido y su clasificación entre los de naturaleza natural e industrial. Entre aquellas destaca el ruido de las industrias, construcción, calles céntricas, barrios residenciales, casas, oficinas, automotores, ferrocarriles, embarcaciones, autos de nieve, sistemas eléctricos, aviación subsónica y supersónica.

${ }^{95}$ Martín Mateo, R., cit. (n. 92), II, p. 602. 
en la persona se materializan en el plano fisiológico y psicológico ${ }^{96}$. Algunos de los efectos que produce la exposición prolongada al ruido son perturbación del sueño, vigilia y fatiga intensificada y, en consecuencia, deterioro del funcionamiento fisiológico y cognitivo de la persona. Se experimenta aumento de la presión sanguínea y vasoconstricción pudiendo desarrollar hipertensión y enfermedades cardiacas. Desarrollo de alteraciones hormonales, gástricas, de coordinación muscular y de habilidades intelectuales tales como pensamiento, memoria, lenguaje, movimiento, etc. Auditivamente genera micro-traumatismos que a largo plazo pueden significar pérdida parcial o total de la capacidad auditiva. Además, afecta el órgano del equilibrio y al Sistema Nervioso Central pudiendo generar vértigos, pérdida del equilibrio y exacerbar síntomas neurológicos en tumores cerebrales o crisis convulsivas en epilépticos ${ }^{97}$. Todos estos efectos dan cuenta que el ruido es un elemento inmisivo que impide al poseedor de un inmueble poder gozar adecuadamente de un inmueble. Tan solo pensemos en una familia que pretende dormir en su inmueble durante las horas de descanso pero los ruidos de pubs o industrias se lo impiden ${ }^{98}$.

${ }^{96}$ Un reciente estudio de la Organización Mundial de la Salud postula que en Europa los hogares de la población de menor condición socioeconómica padece con mayor intensidad las molestias ocasionadas por el ruido, particularmente el producido por el tránsito vehicular, causando un millón de muertes anuales en Europa occidental. La inequidad social a causa del ruido es expuesta por estas estadísticas y es conveniente que en Chile se tome conciencia que la materia en estudio debe ser abordada con políticas públicas pues afecta ámbitos tan diversos como la equidad social, económica y la salud. Véase: Environmental Health Inequialities in Europe. Assessment Report (World Health Organization. Regional office for Europe, 2012), pp. 92-94, disponible en http://www. euro.who.int/_data/assets/pdf_file/0010/157969/e96194.pdf (consultado el 21 de diciembre de 2012).

${ }^{97}$ Véase Brizuela, Mónica, Contaminación sonora. Efectos del ruido ambiental en la salud infantil, ahora en AA. VV., Manual de salud ambiental infantil para enseñanza de grado en Escuelas de Medicina (Santiago, LOM Ediciones, 2009), pp. 139-143. Martín Mateo, R., cit. (n. 92), II, pp. 616-618, denuncia los efectos ecológicos y materiales que el ruido genera y expone sus consecuencias económicas. Por último, al lector interesado recomendamos GRAU, J., cit. (n. 90), pp. 180-199 por la distinción que realiza entre efectos otológicos, psíquicos y fisio-patológicos, al igual que la explicación del "Síndrome General de Adaptación" como mecanismo de respuesta del ser humano ante el agente sonoro.

${ }^{98}$ A mayor abundamiento, en Labbé Opazo, Francisco, Censo 2012. Resultados preliminares censo de población y vivienda, Instituto Nacional de Estadística, disponible en http://www.censo.cl/2012/08/resultados_preliminares_censo_2012.pdf (consultado el 25 de enero de 2013) se expone que en nuestro país viven 16.572 .465 personas y solo en la Región Metropolitana residen 6.683 .852 lo que representa un 40,33\% de la población nacional. La extrema densidad demográfica provoca entre otros inconvenientes que sus habitantes estén expuestos a altos niveles de ruidos. Conforme con el 
Es por esto que el circunspecto estudio de la protección jurídica privada por molestias acústicas es vital pues en Chile el ruido es un factor de permanente distorsión que transgrede directamente el bienestar de la persona y asimismo, molesta e impide total o parcialmente ejercer las facultades del dominio sobre un inmueble.

\section{Sostén normativo de la teoría en el ordenamiento nacional.}

El esfuerzo por explicar la teoría de las inmisiones, su origen, concepto actual, clasificación y definición sería en vano en la medida que no tuviera respaldado normativo. La extensa tradición de la teoría que rememora sus orígenes a los cuerpos romanos y cuya aplicación es directa y objeto de diversos estudios en otros ordenamientos, no concebiría sustento en el nuestro de no mediar fundamento legal.

Chile se encuentra en el ámbito de los ordenamientos privados que cuentan con una referencia directa a la disciplina de las inmisiones pero que carecen de norma general positiva. Es por esto que abogamos por su construcción dogmática a partir de los artículos 582, 856 y 941 inciso $1^{\circ}$ CC. ${ }^{99}$. Esto, esperamos, promoverá su directa aplicabilidad por parte de los tribuales patrios ${ }^{100}$.

estudio realizado en el año 2006 por IÑIguez, Rodrigo y otros, Medición de los niveles de ruido ambiental en la ciudad de Santiago de Chile, en Revista de Otorrinolaringología y Cirugia de Cabeza y Cuello, 67 (2007) 2, pp. 122-128, Santiago es una ciudad altamente ruidosa que ordinariamente sobrepasa los límites internacionales y nacionales de presión sonora máxima en los distintos ámbitos de la vida social.

${ }^{99}$ A mayor abundamiento, en Alessandri, A. - Somarriva, M. - Vodanovic, A., Tratado, cit. (n. 3), I, p. 103 n. 141, se exponen disposiciones positivas que permiten deducir un principio de vecindad para evitar toda "inmisión o influencia nociva en el predio vecino". Los tres primeros artículos que se citan son precisamente los que enunciamos como fuente de la teoría de las inmisiones. De hecho, se hace presente que las normas no pueden ser taxativas y por lo tanto permiten una in terpretación generalizadora.

${ }^{100}$ Explica Macías Castillo, A., cit. (n. 8), pp. 93-112, que en España, la omisión literal en el Derecho positivo de la prohibición de inmitir ha sido salvada por su construcción jurisprudencial en función del artículo 590 CCEsp., redactado en términos muy semejantes a nuestro artículo 856 . Además se suele utilizar como fundamento el artículo $1.908 \mathrm{del}$ mismo cuerpo legal el cual hace responsable expresamente a los propietarios por los daños ocasionados por los humos excesivos que sean nocivos para las personas o las propiedades. Asimismo, otros lo fundamentan es el artículo 7.2 CCEsp. que reza sobre el abuso del derecho. El autor ofrece el respaldo que existe en la dogmática peninsular para fundar la teoría de las inmisiones únicamente en el artículo 590. A mayor abundamiento, en el ordenamiento jurídico catalán se dictó hace varios años la Ley $\mathrm{N}^{\circ} 13 / 1990$, de 9 de julio, denominada De la acción negatoria, inmisiones, servidumbres y relaciones de vecindad. 
En primer lugar, un fundamento cardinal de la teoría se encuentra en el artículo 582 CC. al precisar que es un límite intrínseco al dominio el derecho ajeno. El planteamiento de dicha restricción en base a una concepción netamente privada revela la trascendencia de las relaciones de vecindad. La teoría de las inmisiones es una vertiente de ellas, por lo que el principio de no hacer en lo suyo lo que se proyecte en lo propio es plenamente concordante y goza de plena vigencia normativa en materia de bienes.

A su vez, el artículo 856 se encuentra ubicado dentro del capítulo de las servidumbres legales, en el cual se distinguen las relativas al uso público o a la utilidad de los particulares. En principio, las inmisiones tienen mayor relación con la vertiente privada de servidumbres sin embargo la enumeración del artículo 841 no evidencia rasgos admisibles a la teoría pues la demarcación, cerramiento, tránsito, medianería, acueducto, luz y vista no son supuestos de inmisiones.

Genera extrañeza ${ }^{101}$ que el artículo 856 se ubique entre las normas dispuestas para la medianería por diversas razones. Primero, porque sencillamente su contenido no dice relación con la materia ${ }^{102}$. Segundo, porque evidentemente no constituye una servidumbre al no existir un predio dominante y otro sirviente, y tercero, porque las servidumbres legales son un límite legal y no por derecho ajeno a la propiedad. Sin embargo, el artículo es trascendente para nuestros propósitos.

Más allá que haya sido históricamente proscripto al derecho administrativo por unos ${ }^{103}$ y concebido como mera regla de policía por otros ${ }^{104}$ lo cierto es que la claridad y sencillez de su redacción impresiona a la luz del estudio al

${ }^{101}$ Recomendamos el artículo de Amunátegui Perelló, C. F., Las relaciones de vecindad, cit. (n. 2), pp. 89-103, que encuentra sentido a la ubicación del precepto por ser fuente del Código Civil chileno la tradición francesa que estableció la regulación de las relaciones de vecindad como servidumbre legal. No así la tradición española de las Partidas, también utilizada como fuente, que destina su regulación a las acciones posesorias, específicamente el artículo 916 del mismo cuerpo legal. En el mismo sentido, Claro Solar, L., Explicaciones de derecho civil chileno y comparado (Santiago, Imprenta Nascimento, 1935), IX, p. 162 n. 1.481, expone que su origen fue el Código Civil francés en donde se regulaba como una servidumbre legal especial.

${ }^{102}$ Hace más de siete décadas Claro Solar, L., Explicaciones, cit. (n. 101), IX, p. 162 n. 1.481 manifestaba su extrañeza por la ubicación de este artículo en el Código Civil.

${ }^{103}$ Resuelve Alessandri, A. - Somarriva, M. - Vodanovic, A., Tratado de los derechos reales. Bienes ( $6^{a}$ edición, Santiago, Editorial Jurídica de Chile, 2001), II, p. 211 n. 1.108, en relación con el comentado artículo que "la Ley sobre Organización y Atribuciones de las Municipalidades, el Código Sanitario y las leyes especiales contienen disposiciones relacionadas con esta materia. Su estudio corresponde al Derecho Administrativo".

${ }^{104} \mathrm{El}$ autor Claro Solar, L., Explicaciones, cit. (n. 101), IX, p. 162 n. 1.481 señala que "son simples medidas limitativas del derecho de propiedad, reglas de policía enca- 
que nos avocamos. Revela en breves líneas los elementos que constituyen la teoría de la inmisión y que han permanecido en la oscuridad durante siglos para nuestro ordenamiento. Sin embargo, para el lector suspicaz es menester comprehender que la norma data del siglo XIX y los supuestos que ofrece no son los mismos que hoy atendemos.

La norma dispone que: "si se trata de pozos, letrinas, caballerizas, chimeneas, hogares, fraguas, hornos u otras obras de que pueda resultar daño a los edificios o heredades vecinas, deberán observarse las reglas prescritas por las ordenanzas generales o locales, ora sea medianera o no la pared divisoria. Lo mismo se aplica a los depósitos de pólvora, de materias húmedas o infectas, y de todo lo que pueda dañar a la solidez, seguridad y salubridad de los edificios".

Pozos, letrinas, caballerizas, chimeneas, hogares, fraguas, hornos, depósitos de pólvora, de materias húmedas o infectas son actividades realizadas en un predio que pueden producir inmisiones, especialmente por olores y humos. Sin embargo la descripción no es taxativa pues menciona " $u$ otras obras y de todo lo que pueda" que manifiestan la aprensión del legislador por no desatender fenómenos inmisivos imponderables de la actividad humana. Ofrece entonces una redacción laxa que abraza nuevas y futuras perturbaciones que puedan dar lugar a inmisiones ${ }^{105}$.

Para que opere la norma la acción estará sujeta a una condición. Constituye el hecho futuro e incierto "que pueda resultar daño a los edificios o heredades vecinas o que pueda dañar". En otras palabras, la emisión no es de por sí considerada negativa. Solo en la medida que pueda resultar daño a los edificios o heredades vecinas es que se observará su aplicación. Denota que la intencionalidad en el daño es irrelevante, pues solo se requiere que la obra, fuente de la turbación, provenga del actuar vecino. Asimismo, trasciende una tutela inhibitoria de actos constitutivos de inmisiones ya que exige la existencia de un peligro y no la consumación del daño.

En consecuencia, al disponer que el daño sea potencial, que la molestia no debe ser directamente querida sino que un efecto reflejo o mediato de la actividad y, además, que necesariamente debe proyectarse en una propiedad ajena, la norma claramente enuncia los elementos de la teoría de la inmisión. A mayor abundamiento, y lo que consideramos de mayor valor, es que al utilizar la palabra "pueda" se abre la posibilidad de una protección cautelar frente a actividades potencialmente peligrosa.

También es destacable la frase "sea medianera o no la pared divisoria" toda

minadas a prevenir los daños que puedan resultar a los edificios o heredades vecinas o que puedan comprometer la solidez, seguridad y salubridad de los edificios [...]".

${ }^{105}$ En el mismo sentido Amunátegui Perelló, C. F., Las relaciones de vecindad, cit. (n. 2), p. 102, quien dice: "la enumeración es, por supuesto, netamente ejemplar [...] Todas las actividades tienen como común denominador la emisión de sustancias fuera del espacio jurídico del inmueble donde se producen". 
vez que evidencia que la colindancia de predios no es factor excluyente sino que complementario en el marco de las relaciones de vecindad. El texto legal ratifica que el legislador no limita la vecindad en términos de contigüidad o medianería. Obviamente que los problemas de convivencia suponen mayor frecuencia entre quienes aprovechan predios próximos pero ello no impide que otros inmuebles también puedan estar afectos al ámbito de influencia inmisiva y que dichos supuestos sean razonados en función de las relaciones de vecindad.

Al mencionar que la obra "pueda dañar a la solidez, seguridady salubridad de los edificios" identifica aquella turbación de la posesión a la que se refiere. Si bien la solidez puede estar más relacionada con los perjuicios materiales de las construcciones, la seguridad y salubridad afectan directamente a quién aprovecha la propiedad. Es difícil pensar que el poseedor de la cosa pueda tranquilamente disfrutar del bien en la medida que exista peligros para las estructuras y, por sobre todo, en la calidad sanitaria del inmueble. Denota una protección refleja de intereses públicos toda vez que la tutela de la inmisión impide que otros bienes jurídicos sean afectados tales como la salud y el medio ambiente. El peligro entonces puede ser tanto material como personal; ambos supuestos de turbación de la posesión de un inmueble o de los derechos reales constituidos en él.

Puede provocar duda el hecho que el artículo remita a "reglas prescritas por las ordenanzas generales o locales" pero la finalidad de dicha remisión no es confinar la norma íntegramente al derecho administrativo sino que de informar al vecino del nivel de tolerancia que debe observar ante la ocurrencia de la inmisión. Es importante señalar que esto no impide al particular afectado ejercer acciones civiles tendientes a la protección de sus derechos e intereses ${ }^{106}$.

A mayor abundamiento, estimamos que no solo de dicha norma se observa la teoría de las inmisiones. Dentro de las acciones posesorias especiales del Código Civil creemos que el artículo $941^{107}$ también da cuenta de ella.

${ }^{106}$ Concordamos con Amunátegui Perelló, C. F., Las relaciones de vecindad, cit. (n. 2), p. 102, cuando señala que la acción que el afectado dispone, además de la querella de amparo en caso de proceder, sería la acción negatoria. Dicha acción, inexistente en nuestro ordenamiento y que podría ser suplida por una meramente declarativa, tiene por objeto que se declare la inexistencia de una servidumbre que autorice al emisor a inmitir en predio ajeno. En suma, procura liberar al inmueble afectado de una perturbación o molestia que el inmitido no está jurídicamente obligado a soportar.

${ }^{107}$ Que reza así: "El dueño de una casa tiene derecho para impedir que cerca de sus paredes haya depósitos o corrientes de agua, o materias húmedas que puedan dañarla.Tiene asimismo derecho para impedir que se planten árboles a menos distancia que la de quince decimetros, ni hortalizas oflores a menos distancia que la de cinco decimetros. Si los árboles fueren de aquellos que extienden a gran distancia sus raices, podrá el juez ordenar que se planten a la que convenga para que no dañen a los edificios vecinos: el máximum de 
Se ha cuestionado la naturaleza de las acciones posesorias especiales, señalando que son " $[. .$.$] acciones que tienden a hacer efectivas las restricciones$ del dominio establecidas para evitar, dentro de las relaciones de vecindad, las 'inmisiones' o influencias extrañas que, directa o indirectamente, puedan perjudicar, en forma más o menos considerable, la propiedad"108. En lo tocante al asunto, más allá de si son acciones posesorias o no, es destacable que reconozca expresamente que el contenido del artículo constituye un supuesto de inmisiones perjudiciales a la propiedad ajena pues refuerza nuestra postura de fundar en ellos la teoría en estudio.

En efecto, es el inciso $1^{\circ}$ del artículo 941 CC. que nos interesa al disponer que el dueño, y sólo él en virtud de la concepción clásica real de relaciones de vecindad, puede impedir que los depósitos, corrientes de agua o materias húmedas ubicadas cerca de sus paredes puedan dañarlas. El caso alude a una inmisión de carácter inmaterial, tal como la humedad, que impide que el propietario pueda gozar plenamente de su dominio pues aquella influencia extraña al predio perjudica ilícitamente la pared de la que es propietario. Es menester señalar que el artículo ofrece una protección posesoria más limitada y acotada que el artículo 856 toda vez que se limita al ejercicio por parte del dueño de una casa cuando tenga justa causa de temer una inmisión potencial a causa de los supuestos de humedad descritos, no siendo procedente por otros fenómenos distintos ${ }^{109}$.

En suma, lo trascendente es concluir que toda inmisión que perturbe el goce de un inmueble debe ser objeto de tutela por parte del Derecho. Los artículos comentados, independiente de la holgura de fenómenos inmisivos previstos, dan cuenta de la validez dogmática de la teoría de la inmisión en nuestro ordenamiento.

la distancia señalada por el juez será de cinco metros. Los derechos concedidos en este artículo subsistirán contra los árboles, flores u hortalizas plantadas, a menos que la plantación haya precedido a la construcción de las paredes".

${ }^{108}$ Alessandri, A. - Somarriva, M. - Vodanovic, A., Tratado, cit. (n. 103), II, p. 391, n. 1.369 .

${ }^{109} \mathrm{El}$ autor Amunátegui Perelló, C. F., Las relaciones de vecindad, cit. (n. 2), p. 112 postula una interpretación de mayor amplitud a causa de la utilización por parte del legislador de la palabra dañarla al referirse a las paredes pues el uso singular del concepto denotaría que "el tipo de daño que puede sobrevenir no se encuentra especificado, por lo que entendemos que puede referirse a todo tipo de inmisión que, de producirse, pudiese resultar perjudicial, como aquellas e humedad o de malos olores, desvirtuando la finalidad habitacional del inmueble". Sin embargo no compartimos esta tesis porque creemos que el uso singular del verbo dice relación con la casa/habitación y no con las paredes siendo la humedad, como fenómeno inmisivo inmaterial, el único que la norma ampara. De lo contrario el legislador podría haber utilizado la misma técnica que en el artículo 856 para ampliar los presupuestos previstos. 


\section{TRATAMIENTO DEL RUIDO EN EL ORDENAMIENTO} ADMINISTRATIVO CHILENO

\section{A diferencia de ordenamientos foráneos que cuentan con un mejor desa- rrollo normativo de la materia ${ }^{110}$, en nuestro país el ruido encuentra una débil}

${ }^{110}$ En particular nos remitiremos a España en donde el ruido es materia de específica y detallada regulación. La Ley $\mathrm{N}^{\circ} 37 / 2003$, de 17 de noviembre, Del ruido, y sus reglamentos es la normativa general en el país. Establece, en resumidas cuentas, diversas definiciones y siete segmentaciones de áreas acústicas con los respectivas delimitaciones y criterios para determinar los usos para cada cual. Además regula la constitución de servidumbres acústicas entorno a infraestructura de transporte aéreo, viario, ferroviario, portuario, entre otras actividades públicas. Define los índices acústicos por períodos (índice de día, de tarde y de noche). Pretende la prevención del ruido mediante la elaboración y regulación de los mapas de ruidos, la planificación territorial, control de emisiones de ruido de vehículos motorizados destinados a servicios de urgencias, embarcaciones de recreo y motos aeronáuticas, aeronaves y aviones subsónicos y la maquinaria de construcción, restricción de los permisos de edificación y la determinación de zonas acústicas especiales. Finalmente, dispone el medio de fiscalización, enumeración de las infracciones y la sanción de conductas contrarias a la Ley. Sin embargo, las comunidades autónomas de España han elaborado su propia normativa. Es del caso mencionar la Ley $\mathrm{N}^{\circ}$ 16/2002: De protección contra la contaminación acústica de Cataluña; Ley $N^{\circ}$ 7/1997: Contra la contaminación acústica de Galicia; Ley $\mathrm{N}^{\circ}$ 3/1998: General de protección del medio ambiente del País Vasco; Ley Foral No 4/2005: De intervención para la protección ambiental y reglamento de desarrollo, de Navarra; Decreto de protección contra la contaminación acústica de Madrid; Ley N 7/1994: De protección ambiental, y reglamento de desarrollo, de Andalucía; Decreto de la Junta de Extremadura $\mathrm{N}^{\circ} 19 / 1997$, de 4 de febrero: Sobre reglamentación de ruidos y vibraciones; Ley $\mathrm{N}^{\circ}$ 1/1995: De protección del medio ambiente de Murcia; Ley Nº7/2002: De protección contra la contaminación acústica, y reglamento de desarrollo, de Valencia; y Ley $\mathrm{N}^{\circ} 1 / 2007$ : Contra la contaminación acústica de Baleares. En cada uno se regula de forma específica el ruido. Véase: MARTí MARTí, Joaquim, La defensa frente a la contaminación acústica y otras inmisiones (Barcelona, Bosch editor, 2008), pp. 15-87. Asimismo, existe referencia al ruido como supuesto de inmisión en la Ley $\mathrm{N}^{\circ}$ 49/1960, de 21 de Julio: Sobre propiedad horizontal española que dispone en su artículo $7 \mathrm{~N}^{\circ} 2$ que: "Al propietario y al ocupante del piso o local no les está permitido desarrollar en él o en el resto del inmueble actividades probibidas en los estatutos, que resulten dañosas para la finca o que contravengan las disposiciones generales sobre actividades molestas, insalubres, nocivas, peligrosas o ilícitas". Faculta al presidente, de oficio o a petición de interesado, solicitar la cesación de la actividad molesta. Lo mismo sucede en la Ley $\mathrm{N}^{\circ} 29 / 1994$, de 24 de noviembre: De arrendamientos urbanos, pues el artículo 27 dispone que el arrendador podrá resolver de pleno derecho el contrato de arrendamiento cuando en la vivienda tengan lugar actividades molestas, insalubres, nocivas, peligrosas e ilícitas. A mayor abundamiento, al ruido ha sido considerado un fenómeno inmisivo en virtud del artículo 590 CCEsp. facultando al afectado ha solicitar su cesación mediante la acción negatoria y la correspondiente indemnización en función de los artículos 1.902 y 1.908 del mismo cuerpo legal. También el artículo 3 de la Ley $N^{\circ} 38 / 1999$, de 5 de noviembre, De la ordenación de la construcción en España, dispone que son requisitos básicos de la edificación, rela- 
y dispersa regulación. Los instrumentos que básicamente tratan el asunto son el Decreto Supremo No 146 de 1997, las ordenanzas municipales, Ley y Ordenanza general de urbanismo y construcciones y Ley sobre copropiedad inmobiliaria ${ }^{111}$.

tivos a la habitabilidad, la "protección contra el ruido, de tal forma que el ruido percibido no ponga en peligro la salud de las personas y les permita realizar satisfactoriamente sus actividades". Este requisito técnico de las condiciones acústicas en los edificios y sus instalaciones fue regulado mediante la dictación del Código Técnico de Edificación (Real Decreto 314/2006 de 17 de marzo y sus posteriores modificaciones), siendo específica y muy detalladamente tratada en el Real Decreto $\mathrm{N}^{\circ} 1.371 / 2007$, de 19 de octubre, por el que se aprueba el documento básico "DB-HR Protección frente al ruido" del Código Técnico de la Edificación. Finalmente es atingente el Real Decreto $\mathrm{N}^{\circ} 2 / 2008$, de 20 de junio, por el que se aprueba el texto refundido de la Ley de Suelo española que tiene por objeto regular las condiciones básicas para el garantizar la igualdad en el ejercicio de derecho y cumplimiento de deberes relacionados con el suelo en el territorio español. El artículo 5 dispone que es un deber de los ciudadanos “cumplir los requisitos y condiciones a que la legislación sujete las actividades molestas, insalubres, nocivas y peligrosas, asi como emplear en ellas en cada momento las mejores técnicas disponibles conforme a la normativa aplicable". A su vez el artículo 29 sobre acción ante los tribunales ordinarios que "los propietarios y titulares de derechos reales, además de lo previsto en el artículo anterior, podrán exigir ante los Tribunales ordinarios la demolición de las obras e instalaciones que vulneren lo dispuesto respecto a la distancia entre construcciones, pozos, cisternas, o fosas, comunidad de elementos constructivos u otros urbanos, asi como las disposiciones relativas a usos incómodos, insalubres o peligrosos que estuvieren directamente encaminadas a tutelar el uso de las demás fincas". Estas normas son relevantes en materias de ruidos pues la ley hace alusión con los términos empleados al Decreto $\mathrm{N}^{\circ} 2.414 / 1961$, de 30 de noviembre, por el que se aprueba el Reglamento de actividades molestas, insalubres, nocivas y peligrosas que dispone expresamente en su artículo 3 que "serán calificadas como molestas las actividades que constituyan una incomodidad por los ruidos o vibraciones que produzcan o por los humos, gases, olores, nieblas, polvos en suspensión o sustancias que eliminen". Regula además específicamente los emplazamientos de estos establecimientos $\mathrm{y}$, asimismo, clasifica minuciosamente las actividades por naturaleza molesta, insalubre, nociva o peligrosa exponiendo con precisión los motivos que explican su encasillado.

${ }^{111}$ Hacemos presente la existencia de normativa que dice relación con ruidos pero que no serán objeto de del presente trabajo por ser ajenas a la inmisión sonora intra-predial. Estas normas son: el Decreto № 129, publicado en el Diario Oficial el 7 de febrero de 2003 que establece la Norma de emisión de ruidos para buses de locomoción colectiva urbana y rural; el Decreto $\mathrm{N}^{\circ} 594$, publicado en el Diario Oficial el 29 de abril del año 2000, que aprueba el Reglamento sobre condiciones sanitarias y ambientales básicas en los lugares de trabajo; y el Decreto $\mathrm{N}^{\circ} 122$, publicado en el Diario Oficial el 19 de enero de 1991, que fija los Requisitos dimensionales y funcionales a vehiculos que presten servicios de locomoción colectiva urbana que indica. Asimismo, en Ponce, M., cit. (n. 88), pp. 181-182, se informa que actualmente están en proceso de elaboración: una Norma de emisión de ruidos generados por actividades de construcción, que incorpora exigencias de tipo preventivas, como por ejemplo una planificación de la obra que minimice las potenciales molestias y una Norma de emisión de ruido para vehiculos livianos, medianos y motocicletas, similar a la norma de ruido de buses. Se establecerán exigencias para el 


\section{El Decreto Supremo $N^{\circ} 146$ de 1997.}

El Decreto $\mathrm{N}^{\circ} 146$, del Ministerio Secretaría General de la Presidencia de la República, titulada Norma de emisión de ruidos molestos generados por fuentes fijas, se promulgó el 24 de diciembre de 1997 y publicó el 17 de abril de 1998. Tuvo origen en la revisión, modificación, actualización y perfeccionamiento del Decreto Supremo № 286, de 1984, del Ministerio de Salud y tiene por objeto proteger adecuadamente a la comunidad de la contaminación acústica provenientes de fuentes fijas. Conforme el artículo 3 letra i) se regula únicamente el ruido originado por un emisor de fuente fija cuando el receptor es la persona ${ }^{112}$.

La norma nos parece tener una denominación poco idónea pues no dice relación con el objeto para el cual se concibió. Su finalidad es evitar los daños que se producen en la persona a causa del ruido. En este sentido, es el principio preventivo que lo informa pues una vez acaecidas las conductas acústicamente molestas el individuo expuesto ya habrá sufrido las consecuencias. En consecuencia, dice mayor relación con ello la designación de "norma de emisión de sonidos tolerables" o "norma de prevención de ruidos". Su actual denominación hace referencia a una perturbación existente que ya ha producido los daños asociados. Su denominación debería fomentar una actividad sonora, inherente al ser humano, dentro de parámetros adecuados en un contexto preventivo. En otras palabras, construirse en función del sonido (ex-ante) y no del ruido (ex-post $)^{113}$.

En el título $3^{\circ}$, su artículo 3 se dispone una serie de definiciones que pueden ser clasificadas entre índices acústicos, niveles de presiones sonoras, respuesta del instrumento, ruidos y zonificación ${ }^{114}$. Para lo tocante al estudio

ingreso al parque automotriz y controles en las revisiones técnicas. Por otra parte, es importante destacar que los instrumentos de gestión ambiental definidos en la Ley $\mathrm{N}^{\circ}$ 19.300, no contemplan una regulación asociada al receptor del ruido que permita, por ejemplo, establecer valores mínimos de calidad acústica para las edificaciones. Con este propósito, se promovió la elaboración de una regulación técnica, no ambiental y de carácter referencial, en el Instituto de Normalización Nacional. Dicha norma reconoce las necesidades de aislamiento acústico de las fachadas de las edificaciones de uso habitacional, en consideración al ruido existente en el lugar donde se pretende emplazar. Si bien esta norma es oficial, en la práctica se utiliza sólo como referencia, ya que no está explícito su uso en la Ordenanza general de urbanismo y construcciones .

${ }^{112}$ Conforme al artículo 3 se entiende por fuente emisora de ruido "toda actividad, proceso, operación o dispositivo que genere, o pueda generar, emisiones de ruido hacia la comunidad". Sin embargo, una fuente fija emisora de ruido es solo "aquella diseñada para operar en un lugar fijo o determinado sin pierden su calidad de tal las fuentes que se hallen montadas sobre un vehiculo transportador para facilitar su desplazamiento".

${ }^{113}$ En un sentido similar se manifiesta Martí Martí, J., cit. (n. 110), p. 15 en relación a la Ley española 37/2003 del Ruido.

${ }^{114}$ Sin embargo extrañamos una definición de sonido, ruido, ruido ambiental y ruidos molestos o intolerables que es el supuesto lógico en el cual se basa el decreto. 
dejaremos de lado las consideraciones técnicas para enfocarnos particularmente en dos elementos que se utilizan para discriminar el máximo nivel sonoro permitido: zona y horario ${ }^{115}$.

El decreto en comento clasifica los usos de suelos permitidos en cuatro zonas de acuerdo a los instrumentos de planificación territorial. La zona I está destinada a uso habitacional y equipamiento a escala vecinal. La zona II corresponde a los usos indicados para la zona I y el equipamiento a escala comunal o regional. La zona III corresponde a lo indicado para la zona II y para industria inofensiva. Finalmente la zona IV corresponde al uso de suelo permitido para industria inofensiva o molesta.

De la norma se infiere que en los lugares habitacionales y de equipamiento a escala vecinal se procura el mayor grado de tranquilidad acústica. Cuando a ello se agregue equipamiento a escala comunal el límite aumenta ${ }^{116}$. En la misma proporción se permite una mayor entidad del ruido en lugares con industrias inofensiva. El máximo de sonoridad será objeto de lugares que cuenten con industria molesta.

El horario ha sido clasificado entre el día (7 a 21 horas) y la noche (21 a 7 horas). Los niveles de presión sonora deberán ajustarse a estos periodos dependiendo de la zona en que se encuentra la fuente emisora. Se permite un mayor índice acústico durante el día que en horas que ordinariamente se destinan al descanso. Destacamos que en el caso de industria molesta no existe distinción horaria y que siempre pueden funcionar con el mayor nivel de sonoridad permitido ${ }^{117}$.

\section{Ordenanzas municipales.}

Cada Municipalidad está llamada a regular los ruidos molestos que acaezcan en sus respectivas comunas. Para estos efectos tomamos como muestra la Provincia de Santiago en virtud que acoge la mayor densidad poblacional en la Región Metropolitana ${ }^{118}$. Para su cotejo las clasificamos

Asimismo, no se define los conceptos de vecindad, equipamiento de escala vecinal, equipamiento de escala comunal, industria inofensiva e industria molesta, los cuales estimamos de toda relevancia por ser conceptos que determinarán el límite de presión sonora corregido y permitido.

${ }^{115}$ Destacamos que el artículo 6 del decreto dispone que la medición del ruido se debe hacer en el lugar donde se encuentre el receptor del ruido y no del lugar del emisor.

${ }^{116}$ No se define el concepto de equipamiento vecinal o comunal. 117

$\begin{array}{lcc} & \text { De } 7 \text { a } 21 \text { Hrs. } & \text { De } 21 \text { a } 7 \text { Hrs. } \\ \text { Zona I } & 55 & 45 \\ \text { Zona II } & 60 & 50 \\ \text { Zona III } & 65 & 55 \\ \text { Zona IV } & 70 & 70\end{array}$

${ }^{118}$ El cotejo se realizó con 27 de las 32 comunas que componen la Provincia de San- 
entre aquellas dictadas con anterioridad al Decreto Supremo No 146 de 1997 y las dictadas con posteridad. Si bien su ámbito de regulación es mayor al meramente predial, pues abarca espacios públicos y no meramente privados, su estudio es relevante porque dará cuenta del tratamiento administrativo de las emisiones sonoras.

El primer grupo, que representa más del $50 \%$ de las normas cotejadas, tiene fecha de publicación entre 1982 y 1993. Por regla general se denominan Ordenanzas sobre de prevención y control de ruidos molestos, sin perjuicio de las incluidas en aquellas sobre Normas sanitarias básicas, bajo el título De la contaminación ambiental. Se observa que en este grupo sí existe uniformidad en la denominación de los instrumentos encargados de regular la materia y es destacable que en la mayoría de los casos se usen las palabras prevención y control, a diferencia del Decreto Supremo No 146 de 1997, porque supone un entendimiento de la función preventiva que se debe desarrollar y no simplemente paliativa del ruido.

Asimismo, entre estas ordenanzas existe una estructura de redacción con elementos idénticos. Comienzan con un primer artículo que describe en términos negativos qué se entiende por ruidos ${ }^{119}$. Se prohíbe todo ruido, sonido o vibración, sin distinción, que produzca molestias al vecindario, perturbe el reposo de la comunidad o cause perjuicio material o moral, exceptuando los ocasionados por ferrocarriles o aviones. Destacamos que se señale el daño moral como consecuencia del ruido pues en este ámbito de molestias difícilmente se podrá ocasionar daños materiales sino que perjuicios a la tranquilidad de los vecinos.

Entre otras cosas, todas reproducen la regulación especial de ciertas actividades como los ruidos producidos por industrias, talleres y locales

tiago: Cerrillos, Conchalí, El Bosque, Estación Central, Huechuraba, Independencia, La Florida, La Granja, La Pintana, La Reina, Las Condes, Lo Barnechea, Lo Espejo, Lo Prado, Macul, Nuñoa, Peñalolen, Providencia, Pudahuel, Quilicura, Quinta Normal, Recoleta, Renca, San Joaquín, San Miguel, Santiago y Vitacura. Se excluye por falta de información las ordenanzas municipales de Cerro Navia, La Cisterna, Maipú, Pedro Aguirre Cerda y San Ramón.

119 "Prohibase todo ruido, sonido o vibración que, por su duración o intensidad ocasiones molestias al vecindario, sea de dia o de noche, que se produzca en el aire, en la vía pública, o en locales destinados a la habitación, al comercio, a la industria, o a diversos pasatiempos.- Queda probibido en general causar, producir, estimular o provocar ruidos molestos, cualquiera sea su origen cuando, por razones de hora, lugar o grado de intensidad, perturben o puedan perturbar la tranquilidad o reposo de la población, o causar cualquier perjuicio material o moral.- Quedan exceptuados de la probibición establecida en el inciso precedente, los ruidos ocasionados o producidos por motores de naves que cruzan el espacio aéreo de la comuna hacia o desde aeropuertos, y los accionados por Ferrocarriles en el desarrollo de su actividad". 
comerciales, de los vehículos en las vías públicas y los provocados por construcciones y demoliciones.

Respecto del segundo grupo, compuesto por las normas posteriores a 1997, dictadas entre 1998 y 2009 , observamos que las ordenanzas son denominadas de manera disímil, perdiendo la uniformidad que caracterizaba al grupo anterior. Reciben el nombre de Ordenanzas sobreprevención y control de ruidos molestos, Ordenanza sobre ruidos, sobre sonidos y ruidos molestos, Ordenanza sobre normas sanitarias básicas, Ordenanza sobre Emisiones de ruidos molestos generados por fuentes fijas, Ordenanza sobre Gestión ambiental y Ordenanzas de la Dirección de Aseo y Ornato. La mayoría dispone del mismo artículo primero en el cual se describen supuestos que pueden provocar ruidos ${ }^{120}$.

La regulación más moderna claramente está influenciada por el Decreto Supremo $\mathrm{N}^{\circ} 146$ pues contiene definiciones propias de dicha normativa que hacen referencia explícita al ruido ocasionado por fuentes emisoras fijas, a las zonas y horarios de los distintas presiones sonoras permitidas y al procedimiento de medición. Otras mencionan la Ley $\mathrm{N}^{\circ}$ 19.300: De bases generales del medio ambiente ${ }^{121}$ en relación a la evaluación de impacto ambiental de la actividad y de las normas que procedan.

Sin perjuicio de estas diferencias, ambos grupos de ordenanzas contienen elementos análogos dignos de ser identificados. Son clasificables en los siguientes grupos: responsabilidad, prohibiciones generales, medición, fiscalización, sanción y excepciones.

Por regla general se entiende responsable de los ruidos al dueño, poseedor o tenedor del bien mueble o inmueble emisor y se considera solidariamente responsable al autor de la acción u omisión o empleadores o representantes legales. Esto comulga con lo expuesto precedentemente respecto que el titular de las relaciones de vecindad no puede ser únicamente el dueño del predio sino todo aquel que aproveche el inmueble. Tanto el propietario, poseedor o mero tenedor que causa o que sufra un ruido molesto debe ser objeto de responsabilidad o capaz de accionar para impedir que continúe o vuelva a

120 "Esta ordenanza regirá para prevenir y controlar todos los ruidos, sonidos y vibraciones producidos por la vía pública, calles, plazas y paseos públicos, en el espacio aéreo, en las salas de espectáculos, eventos de reuniones, casas o locales de comercio de todo género; iglesias y casa religiosas; $y$ en todos los inmuebles y lugares en que se desarrollen actividades públicas o privadas, asi como en las casas-habitación, individuales o colectivas./ En general queda probibido todo ruido o sonido que por su duración e intensidad ocasione molestias al vecindario sea de dia o de noche, que se produzca en el aire, en la vía pública o locales destinados a la habitación, al comercio, a la industria o a diversiones o pasatiempos".

${ }^{121}$ Publicada en el Diario Oficial el 9 de marzo de 1994. 
ocurrir. Solo se necesita algún tipo relación con el inmueble inmitido, independiente del título que lo justifique, para poder solicitar tutela.

La mayoría de las ordenanzas además dispone de una serie de prohibiciones especiales que a pesar de no ser idénticas se ajustan a una estructura similar y que suponen el bien común. Entre otros, se prohíbe el uso de alto parlantes, radios y de cualquier instrumento capaz de producir sonidos al exterior, como medio de propaganda en el exterior de los negocios. Conversaciones en voz alta después de las 23:00 horas en la vía pública sostenidas por personas estacionadas frente a casas habitacionales. Las canciones, la música y algarabía, ya sea que los ejecutantes vayan a pie o en vehículos. Hacer estallar cohetes, petardos o toda otra materia detonante en cualquier época del año. El funcionamiento de bandas en la vía pública, el proferir gritos o pregones, usar pitos, campanillas u otros instrumentos en forma persistente o exagerada o producir esos gritos o ruidos en las puertas mismas de las viviendas o negocios y ciertas restricciones a la actividad de ferias de diversiones, carruseles, ruedas giratorias o cualquier otro entretenimiento semejante.

La medición debe ser instrumentalizada a objeto de evitar apreciaciones subjetivas. Las ordenanzas más modernas se remiten a los instrumentos dispuestos por el Decreto Supremo $N^{\circ} 146$ y otros los describen. Además en caso que la Municipalidad tenga dudas respecto del ruido podrá solicitar al Servicio de Salud y otro organismo autorizado por él para que realice las mediciones.

La fiscalización de las disposiciones contenidas en las ordenanzas las efectuarán Carabineros de Chile, miembros de los distintos departamentos municipales o los inspectores municipales, sin perjuicio de los demás organismos competentes para conocer. Los fiscalizadores que identifiquen ruidos que contravengan la normativa vigente harán la correspondiente denuncia en el Juzgado de Policía Local respectivo para que sancione.

La sanción a la que se expone el emitente es por regla general multa entre media y diez UTM. En ocasión de reincidencia se prevé aumento progresivo de la multa y la suspensión o clausura de la actividad por el tiempo que el juez estime pertinente. Debemos señalar que en los casos en que la materia es regulada mediante una Ordenanza municipal sobre normas sanitarias Básicas, la producción de ruidos debe ser sancionada a través de los reglamentos de copropiedad existentes, y en subsidio, por el Juzgado de Policía Local.

Por último, la mayoría de los municipios explícitamente reserven la facultad de suspender estas disposiciones reglamentarias por medio de decretos municipales en ocasiones extraordinarias, festivos u otros. 


\section{Respecto de la "Ley y Ordenanza general de urbanismo y construccio- nes".}

El ruido se vincula con la Ley general de urbanismo y construcciones y la Ordenanza general porque contienen normativa relacionada a la planificación urbana, urbanización y construcción en el territorio de la República. Las Municipalidades serán los organismos encargados de su aplicación por lo que se vincula con el Derecho administrativo. Los Juzgados de Policía Local son competentes para conocer de su infracción sin perjuicio de las sanciones que puedan imponer.

El título $2^{\circ}$, párrafo $7^{\circ}$, de la Ley general dispone que si un establecimiento no cumple con las normas de seguridad, reparación y reparación de edificios, la Municipalidad estará facultada para fijar un plazo no menor a un año contado desde la resolución administrativa para que el establecimiento que genere ruido u otro tipo de molestia al vecindario se retire del sector donde se ubica. Asimismo, podrá clausurar los locales comerciales o industrias que contravengan la Ley o la Ordenanza General o las locales. Además, particularmente prohíbe la producción de ruidos molestos por viviendas sociales o industrias (artículos 20 y 162).

Por su parte, la Ordenanza general de urbanismo y construcciones dispone en el título $4^{\circ}$, capítulo $1^{\circ}$, sobre las Condiciones de habitabilidad en las edificaciones destinadas a viviendas, hospedaje, oficinas y comercio. Entre otros aspectos, las clasifica según el nivel de emisión e inmisión acústica y las somete a exigencias particulares. Distingue entre locales que deben ser totalmente aislados ${ }^{122}$, parcialmente aislados ${ }^{123}$, sin exigencia acústica ${ }^{124} y$ locales ruidosos ${ }^{125}$. Regula además el aislamiento sonoro que deben tener los elementos constructivos de las paredes entre unidades de viviendas contiguas y dispone que las instalaciones mecánicas que puedan producir trepidaciones sonoras a los otros moradores de un edificio deban ser evitadas mediante la utilización de mecanismos de aislamiento.

El título $4^{\circ}$, capítulo $14^{\circ}$ de la Ordenanza, sobre establecimientos industriales o de bodegaje dispone que la respectiva Secretaría Regional Ministerial de Salud las clasificará en virtud de los riesgos que su funcionamiento pueda

${ }^{122}$ Estudios de grabación de películas, cinematográficas o de discos, salas de transmisión de radiotelefonía, salas de hospitales, de estudios de música, de escuelas, bibliotecas y audición de alta calidad.

${ }^{123}$ Hoteles, departamentos, casas habitación, locales destinados al culto, oficinas profesionales o comerciales y las otras salas de audición no comprendidas en los locales totalmente aislados.

${ }^{124}$ Estadios, restaurantes y mercados.

${ }^{125}$ Fábricas, estaciones de ferrocarril, centrales o subestaciones eléctricas, imprentas y salas de baile. 
causar al vecindario, comunidad y trabajadores entre los que se contempla el ruido emitido. La Municipalidad podrá disponer que en los deslindes de estos establecimientos sean utilizados dispositivos o elementos que eviten la producción de ruidos.

El título $5^{\circ}$, capítulo $8^{\circ}$ del mismo cuerpo legal dispone que en todo proyecto de construcción, reparación, modificación, alteración, reconstrucción o demolición el responsable de la obra debe procurar evitar los ruidos molestos. Además, las faenas de construcción son concebidas como fuentes transitorias de emisión de ruido por lo que previo al inicio de las obras el ejecutante deberá entregar a la Municipalidad un lista que contenga, entre otras varias cosas, las herramientas y equipos productores de ruidos. La Dirección de Obras en determinados supuestos podrá autorizar una actividad ruidosa y exigir otras medidas de mitigación.

Finalmente, contempla normativa especial relativa a la producción de ruido en ascensores y montacargas y asimismo, cuando se destinen nuevas o existentes edificaciones para emplazamientos de educación (artículos 5.9.5 y 4.5.4 respectivamente).

\section{De la "Ley" y el "Reglamento sobre copropiedad inmobiliaria".}

La Ley $\mathrm{N}^{\circ}$ 19.535: de Copropiedad Inmobiliaria, publicada en el Diario Oficial el 16 de diciembre de 1997, dispone en su artículo 1 que la ley “regula un régimen especial depropiedad inmobiliaria, con el objeto de establecer condominios integrados por inmuebles divididos en unidades sobre las cuales se pueda constituir dominio exclusivo a favor de distintos propietarios, manteniendo uno o más bienes en el dominio común de todos ellos. Los inmuebles que integran un condominio y sobre los cuales es posible constituir dominio exclusivo, pueden ser viviendas, oficinas, locales comerciales, bodegas, estacionamientos, recintos industriales, sitios y otros".

Su estudio en materia de ruido es significante porque cada día se vuelve más cotidiana la convivencia en edificios destinados a oficina o habitación. La vecindad vertical toma relevancia en las ciudades con gran densificación poblacional, limitado terreno disponible y una concentrada oferta de servicios. Además, las pugnas entre vecinos encuentran su origen en la cercanía de los inmuebles y en las copropiedades dicho factor se observa en su mayor esplendor.

El artículo 32 dispone que "los copropietarios, arrendatarios u ocupantes a cualquier titulo de las unidades del condominio, deberán ejercer sus derechos sin restringir ni perturbar el legitimo ejercicio de los derechos de los demás ocupantes del condominio" e identifica como contrario a la tranquilidad y al orden la producción de ruidos en horas que ordinariamente se destinan al descanso. Este enunciado refleja la máxima romana que hemos comentado 
previamente en función del pasaje del Digesto sobre los humos producidos por una fábrica de quesos: "in suo enim alii hactenus facere licet, quatenus nibil in alienum immittat". La ley lo reproduce en el marco de la copropiedad inmobiliaria pero no perdería validez alguna en función de propiedades individuales cercanas. Alabamos que no se haya limitado al título de propietario las relaciones que regula sino que se hayan ampliado al arrendatario y ocupante. Culmina el artículo disponiendo que su infracción se sancionará con multa impuesta por el Juzgado de Policía Local sin perjuicio de la acción civil que corresponda. Serán solidariamente responsables el infractor y el propietario de la respectiva unidad habitacional, pudiendo éste último repetir contra el primero.

El Reglamento de copropiedad inmobiliaria, publicado en el Diario Oficial el 17 de junio de 1998, se limita a reproducir lo expuesto previamente.

\section{De la PROTECCIÓN JURÍDico CIVIL FRENTE}

AL RUIDO EN CHILE

El estudio legal del ruido puede resultar farragoso para quien se aproxima incipientemente. Denotamos la protección administrativa que la materia ha adquirido en la legislación. Tanto las leyes, reglamentos y ordenanzas comentadas regulan la materia desde la perspectiva de la emisión. En otras palabras, se norma la causa y no la consecuencia ${ }^{126}$. Estimamos inconveniente radicar exclusivamente su tratamiento en los órganos del Estado pues la contingencia no siempre dirá relación con entes políticos.

Precisamente la inmisión, como contrapartida a la emisión, es el factor determinante de la actuación del afectado. Es una esfera diversa, no excluyente, del tratamiento administrativo. El particular impedido de poseer tranquilamente su predio a causa de episodios sonoros ajenos debe saber que cuenta con una batería de acciones y recursos tendientes a dar tutela al caso concreto. El ruido es un fenómeno que ha devenido en las sociedades modernas como una injerencia de suma importancia y el particular vulnerado por una inmisión de esta naturaleza debe conocer y ejercer las herramientas legales que el ordenamiento ha previsto para su protección. El tratamiento de la inmisión no debe versar en el monopolio de una rama del Derecho sino más bien del compromiso conjunto de todas ellas para ofrecer, desde las diversas perspectivas, una adecuada protección.

El ordenamiento jurídico privado ofrece, desde la óptica de las relaciones entre particulares o de éstos con los órganos del Estado cuando actúan

\footnotetext{
${ }^{126}$ Ejemplo de esto es que las multas son a beneficio municipal y no del afectado.
} 
como personas privadas ${ }^{127}$, el ámbito idóneo de protección de las inmisiones sonoras.

\section{El recurso de protección como medio ordinario de tutela.}

El recurso de protección es un instrumento recurrentemente utilizado en la materia ${ }^{128}$. Sin perjuicio que la jurisprudencia no estila la terminología de inmisión las causas de pedir que dan origen a los Recursos denotan que los pronunciamientos recaen en los supuestos propios de dicha teoría.

La casuística de los ruidos vecinales es inagotable. Los hechos que motivan los Recursos existentes dicen relación con trepidaciones sonoras provocadas por vecinos ${ }^{129}$, locales y establecimientos comerciales ${ }^{130}$, actividades televisivas y religiosas ${ }^{131}$, pubs, discotecas y restaurants ${ }^{132}$, utilización de espacios

${ }^{127}$ Figueroa YÁnez, Gonzalo, Curso de derecho civil (3 3 edición, Santiago, Editorial Jurídica de Chile, 1995), I, p. 2.

${ }^{128} \mathrm{El}$ primer recurso que hace alusión indirectamente al ruido molesto es de 1983 fundado en la instalación de ventiladores de un edificio. Vésase Corte Suprema, 4 de mayo de 1983 , rol $\mathrm{N}^{\circ} 16.575$.

${ }^{129}$ Corte de Apelaciones de Puerto Montt, 23 de septiembre de 2010, rol No 1842010, por ruidos estridentes; Corte Suprema, 8 de agosto de 2000, rol N ${ }^{\circ} 2.586-2000$ por la utilización de un instrumento musical a horas inadecuadas.

${ }^{130}$ Corte de Apelaciones de Santiago, 13 de julio de 1989, rol N ${ }^{\circ}$ 57-89, respecto de una fabrica de carrocerías remolques; Corte Suprema, 20 de abril de 1994, rol N ${ }^{\circ}$ 4.117, en relación a la actividad de una panadería; Corte Suprema, 14 de noviembre de 1985 , rol $\mathrm{N}^{\circ} 20.146$, en función de un local comercial de cabaret y la orquesta que en él tocaba; Corte de Apelaciones de Valparaíso, 20 de enero de 2010, rol ํㅜ 439-2009, por los ruidos de un establecimiento canil; Corte de Apelaciones de Concepción, 6 de septiembre de 1990, en Fallos del Mes, 382, p. 471, en ocasión de los llantos de los niños en un hogar de menores; Corte Suprema, 3 de julio de 2000, rol № 2000-00, por la actividad deportiva, social y cultural que se desarrolla en el gimnasio de una escuela aledaña.

${ }^{131}$ Corte de Apelaciones de Santiago, 18 de junio de 2003, rol N 0001-2003; Corte Suprema, 1 de agosto de 2002, rol N².687-2002.

${ }^{132}$ Corte de Apelaciones de San Miguel, 2 de noviembre de 2009, rol N ${ }^{\circ} 270-2009$; Corte de Apelaciones de Chillán, 6 de septiembre de 2011, rol No 92-11; Corte Suprema, 15 de diciembre de 1999, rol No 3.595-99; Corte de Apelaciones de Puerto Montt, 15 de diciembre de 2011, rol No 301-11; Corte de Apelaciones de Santiago, 4 de octubre de 2012, rol N²0865-2011; Corte de Apelaciones de Arica, 15 de marzo de 1993, rol N³.306; Corte de Apelaciones de Iquique, 23 de diciembre de 2005, rol $\mathrm{N}^{\circ}$ 23-2005; Corte de Apelaciones de Puerto Montt, 04 de octubre de 2006, rol N ${ }^{\circ}$ 182-2006; Corte de Apelaciones de Puerto Montt, 31 de marzo de 2009, rol N²932008; Corte Suprema, 27 de enero de 2010, rol N 9488-2009; Corte de Apelaciones de Concepción, 18 de junio de 2010, rol No 64-2010; Corte de Apelaciones de Rancagua, 23 de febrero de 2011, rol N 1047-2010. 
públicos ${ }^{133}$, carreras de motocicletas ${ }^{134} \mathrm{y}$ automóviles ${ }^{135}$, fiestas privadas ${ }^{136}$, actividades de construcción ${ }^{137}$, obras de ampliación y remodelación ${ }^{138}$ y de la industria ${ }^{139}$.

Todos los recursos acogidos se fundamentan en la vulneración del artículo $19 \mathrm{~N}^{\circ} 8 \mathrm{CPol}^{140}$ al acreditar que se ha excedido de los límites máximos de presión sonara corregidos establecidos en el Decreto Supremo $N^{\circ} 146$ de 1997 o por infringir las ordenanzas locales que regulan la materia ${ }^{141}$. Llama la atención que en la mayoría de los casos en conjunto con el numeral 8 se invoque la infracción del número 1 , esto es, la integridad física y psíquica de la persona. Sin embargo generalmente se acogen sólo por el derecho a vivir en un medio ambiente libre de contaminación sin perjuicio que se considere plausible la infracción del numeral primero cuando se acredita fehacientemente que el ruido ha ocasionado un perjuicio a la salud ${ }^{142}$.

${ }^{133}$ Corte Suprema, 10 de agosto de 2010, rol N³374-2010, por la utilización de un pasaje en zona habitacional para la carga y descarga de mercadería.

${ }^{134}$ Corte de Apelaciones de Arica, 30 de mayo de 2006, rol N ${ }^{\circ}$ 95-2006.

${ }^{135}$ Corte de Apelaciones de San Miguel, 10 de mayo de 2005, cita "Microjuris": MJJ17441.

${ }^{136}$ Corte de Apelaciones de Arica, 31 de marzo de 2011, rol N 61-11; Corte de Apelaciones de Arica, 7 de mayo de 1992, rol N²981-1992.

${ }^{137}$ Corte de Apelaciones de Antofagasta, 23 de enero de 2010, rol No 806-2009; Corte de Apelaciones de Santiago, 10 de julio de 2010, rol N 3.657-99; Corte de Apelaciones de Valparaíso, 21 de diciembre de 2008, rol № 458-2007. Los dos primeros recursos dan cuenta de la postura de distintas Cortes de Apelaciones que consideran a la construcción como una actividad que no pueda ser calificada como fuente fija de emisiones sino que es absolutamente transitoria y por lo tanto no le es aplicable los límites sonoros regulados en el Decreto Supremo $\mathrm{N}^{\circ} 147$ de 1997. Dicha postura es radicalmente contraria con lo dispuesto por la Contraloría General de la República. Véase: Contraloría General de la República, 29 de mayo de 2009, Dictamen Nº 28126 sobre emisión de ruidos molestos en la actividad constructora.

${ }^{138}$ Corte de Apelaciones de Santiago, 15 de marzo de 1994, rol № 2277-1993.

${ }^{139}$ Corte de Apelaciones de San Miguel, 15 de abril de 2008, rol No 67-06; Corte Suprema, 19 de enero de 1997, rol N²830-1997, por los ruidos de una planta chancadora de ripio que extraía áridos.

${ }^{140}$ Recomendamos para conocer el origen, elementos y características del recurso de protección en materia ambiental: BERTELSEN REPETTO, Raúl, El recurso de protección $y$ el derecho a vivir en un medio ambiente libre de contaminación. Examen de quince años de jurisprudencia en Revista Chilena de Derecho, 25 (1998)1, pp. 139-174.

${ }^{141}$ Por regla general las cortes de nuestro país resuelven los casos disponiendo el cese, abstención o la prohibición de la actividad emisora durante ciertos horarios o hasta que se ejecuten las obras tendientes a mitigar el ruido con la finalidad de restablecer el imperio de Derecho y asegurar la debida protección del recurrente.

${ }^{142}$ En una ocasión se impetró que el ruido implicaba un menoscabo al derecho a la salud (artículo $19 \mathrm{~N}^{\circ}$ 9) pero la Corte resolvió que aquel derecho solo ampara la libre 
Para efectos de inmisiones, es dable destacar que en dos ocasiones se fundó el Recurso en la infracción del artículo $19 \mathrm{~N}^{\circ} 24 \mathrm{CPol}$. en conjunto con el $\mathrm{N}^{\circ} 8$. En la oportunidad que se acogió, el recurrente expresamente arguyó que su propiedad era objeto de ruidos, ratones, olores e incluso un incendió a causa de la panadería vecina. Dicho de otro modo, lo que el accionante denunciaba era la imposibilidad de ejercer una posesión tranquila en su propiedad a causa de las inmisiones originadas en el inmueble ajeno. La Corte Suprema, expresamente dispone en el considerando 9 que los “[...] hechos que provienen de la recurrida y que se estiman arbitrarios e ilegales y que perturban y amenazan esos derechos garantizados por los Nos 8 y 24 del artículo 19 de la Constitución Política de la República, esto es, el derecho a vivir en un medio libre de contaminación y el derecho a la propiedad, razón por la cual el recurso tendrá que ser acogido"143. Tanto los hechos como el derecho expuestos en la resolución denotan un clásico caso de inmisiones. Sin embargo fruto de la ignorancia de la teoría, el recurrente no esbozó adecuadamente el Recurso respecto de la protección de la propiedad y asimismo, la Corte no evidenció razones jurídicamente relevantes para resolver conforme al artículo $19 \mathrm{~N}^{\circ} 24$.

La teoría de las inmisiones en materia Constitucional abre las puertas para una nueva lectura de los eventos en comento. Se podrán continuar fundando las resoluciones en el derecho a vivir en un medio ambiente libre de contaminación cuando se vulneren los límites sonoros permitidos. La pregunta es ¿cuando ello no ocurra, ¿se estará impedido del recurso de protección? Postulamos que sin excluir la aplicación del artículo $19 \mathrm{~N}^{\circ} 8$, el derecho de propiedad puede ser razón suficiente para incoar el Recurso, aun cuando no exista transgresión de la normativa administrativa, toda vez que el ruido y otras injerencias impiden la posesión tranquila de un inmueble siendo una razón suficiente de amparo.

A mayor abundamiento, a partir de fines del siglo pasado, el Tribunal Europeo de Derechos Humanos ha resulto asiduamente que el ruido vulnera los derechos contemplados en el artículo 8.1 del Convenio europeo de derechos bumanos, esto es, el derecho a la vida privada y a la protección del domicilio. Dispone que la administración pública debe evitar que estos derechos sean afectados e intervenir ante su acaecimiento ${ }^{144}$. Dicha jurisprudencia, aunque

elección del sistema de salud por lo que no se consideró que el ruido lo vulnerara. Corte de Apelaciones de Arica, 15 de marzo de 1993, rol N³.306.

${ }^{143}$ Corte Suprema, 20 de abril de 1994, rol No 4.117.

${ }^{144}$ Recomendamos las siguientes sentencias de la Corte Europea de Derechos $\mathrm{Hu}$ manos: "López Ostra con España", de 9 de diciembre de 1994; "Moreno Gómez con España”, de 16 noviembre de 2004; "Martínez Martínez con España”, de 18 de octubre de 2011. Para estos efectos véase: García Ureta, A., El ruido ante el Tribunal Euro- 
extraña a nuestro ordenamiento, puede ser el punto de partida para determinar el real sentido y alcance de las garantías constitucionales conculcadas por la inmisión sonora.

\section{Procedimiento ante el Juzgado de Policia Local.}

Conforme al artículo $131^{\circ}$ letra b) y $2^{\circ}$ de la Ley $\mathrm{N}^{\circ} 15.231$ : sobre Organización y Atribuciones de los Juzgados de Policía Local, los jueces son competentes para conocer en primera instancia de la infracción a las ordenanzas, reglamentos, acuerdos municipales, decretos de la alcaldía y a la Ley general de urbanismo y construcciones. Hemos visto que tanto las ordenanzas locales y la Ley de urbanismo y construcciones regulan el ruido. A mayor abundamiento, los conflictos que se originen por infracción de la Ley copropiedad inmobiliaria en conjunto con su respectivo Reglamento serán de competencia de los Juzgados de Policía Local.

Quien sea afectado por las inmisiones sonoras podrá interponer una denuncia o una demanda de indemnización. La denuncia tiene por finalidad poner en conocimiento del Juzgado una actividad que ha infringido la normativa vigente para que sea multada. La acción civil de indemnización de perjuicios tiene por objeto que el afectado reciba una compensación económica por los daños materiales y morales sufridos. Sin embargo para que el Juzgado pueda conocer de una acción civil es menester que ésta sea interpuesta oportunamente dentro del procedimiento contravencional ${ }^{145}$. En consecuencia, no es factible que el Juzgado se pronuncie respecto de la solicitud de una indemnización si no se presenta en conjunto con la denuncia infraccional.

El juez establecerá la multa pertinente por la infracción acaecida y, si es procedente, se pronunciará sobre la responsabilidad del denunciado para efectos de la indemnización. Es relevante destacar que el artículo 52 de la Ley $\mathrm{N}^{\circ}$ 15.231 dispone que es facultativo de los jueces de Policía Local aplicar como sanción, entre otras, la clausura hasta por 30 días de la actividad ruidosa.

Probablemente los Juzgados de Policía Local, como órgano jurisdiccional, sean los que conocen con mayor frecuencia de las inmisiones producto de las relaciones de vecindad sin embargo lamentamos que no exista recopilación de su jurisprudencia para poder comentarla.

peo de Derechos Humanos. Otra llamada de atención a la jurisdicción contencioso-administrativa (y también al Tribunal Constitucional): Comentario a "Martínez Martinez v. España”, sentencia del TEDH de 18 de octubre de 2011, en Revista Actualidad Jurídica Ambiental, 7 (2011), pp. 15-26.

${ }^{145}$ Artículo 19 de la Ley $N^{\circ}$ 18.287: sobre Procedimiento ante los Juzgados de Policía Local. 


\section{Respecto de las acciones contenidas en la "Ley de bases generales del medio ambiente". \\ El artículo 2 de la Ley N 19.300: sobre Bases Generales del Medio Ambien-} te contiene un cúmulo de definiciones atingentes al ruido. La amplitud del concepto legal de medio ambiente promueve su laxitud e indeterminación ${ }^{146}$. La Ley explícitamente define al ruido como un elemento contaminante pues su presencia en el ambiente puede implicar un riesgo para la salud de las personas o la calidad de vida de la población ${ }^{147}$. En consecuencia, no existe un medio ambiente libre de contaminación cuando la entidad acústica sobrepasa los límites determinados por la legislación vigente ${ }^{148}$. Exclusivamente en dicho supuesto el ruido es fuente de contaminación ${ }^{149}$.

Para los efectos del presente trabajo interesa señalar que las acciones que contempla la Ley se podrán ejercer cuando exista responsabilidad por daños ambientales. La amplitud del término medio ambiente brinda la posibilidad de concebir la existencia de un daño ambiental, en los términos legales producto de los ruidos pues la contaminación acústica afecta la salud de las personas y la calidad de vida de la población y, por subsiguiente, al medio ambiente ${ }^{150}$.

El título $3^{\circ}$ de la ley, rubricado: De la responsabilidad por daño ambiental, dispone de una acción de reparación ambiental y otra de indemnización. Para ambas acciones es menester que exista un daño ambiental, elemento que sin embargo es de difícil acreditación procesal. Cuando exista infracción al Decreto Supremo $N^{\circ} 146$ la carga de prueba se invierte pues el artículo 52 dispone que se presume legalmente la responsabilidad del autor del daño ante

\footnotetext{
${ }^{146}$ Se define "medio ambiente" como "el sistema global constituido por elementos naturales y artificiales de naturaleza física, química o biológica, socioculturales y sus interacciones, en permanente modificación por la acción humana o natural y que rige y condiciona la existencia y desarrollo de la vida en sus múltiples manifestaciones".

${ }^{147}$ Se entiende por contaminación contaminante todo "elemento, compuesto, sustancia, derivado quimico o biológico, energía, radiación, vibración, ruido, o una combinación de ellos, cuya presencia en el ambiente, en ciertos niveles, concentraciones o periodos de tiempo, pueda constituir un riesgo a la salud de las personas, a la calidad de vida de la población, a la preservación de la naturaleza o a la conservación del patrimonio ambiental'.

${ }^{148} \mathrm{El}$ medio ambiente libre de contaminación es "aquél en el que los contaminantes se encuentran en concentraciones y periodos inferiores a aquéllos susceptibles de constituir un riesgo a la salud de las personas, a la calidad de vida de la población, a la preservación de la naturaleza o a la conservación del patrimonio ambiental".

${ }^{149}$ Se considera contaminación "la presencia en el ambiente de sustancias, elementos, energía o combinación de ellos, en concentraciones o concentraciones y permanencia superiores o inferiores, según corresponda, a las establecidas en la legislación vigente".

${ }^{150} \mathrm{El}$ daño ambiental es "toda pérdida, disminución, detrimento o menoscabo signifcativo inferido al medio ambiente o a uno o más de sus componentes”.
} 
la infracción de una norma de emisión. La presunción ha sido concebida para facilitar la acreditación de la responsabilidad ambiental y como desincentivo de las actividades contravencionales. Su aplicación significa que la infracción de la norma exime de la prueba del daño al demandante, eliminando el escollo más complejo de la responsabilidad ambiental, y en consecuencia se crea un estímulo importante para entablar las acciones que contempla la Ley.

El afectado por la inmisión sonora puede ejercer la acción de reparación ambiental. Conforme a la legislación vigente el ruido puede ser fuente de un daño ambiental cuando la contaminación acústica produzca efectivamente un menoscabo significativo a la salud de las personas y a la calidad de vida de la población por tratarse de componentes del medio ambiente ${ }^{151}$. La contaminación sonora produce efectos solo a las personas expuestas pero no en el entorno. Pareciera que en el supuesto de ruidos el petitum de la demanda recaería en el cese de la actividad molesta y no en una reparación material de bienes ambientales. La Corte Suprema ratifica en un reciente fallo que reparar el medio ambiente implica adoptar las medidas indispensables para una corrección que acerque el actual estado de cosas a la situación previa a la de su malograda intervención, es decir, a aquella calidad similar a la que tenían con anterioridad al daño causado (Corte Suprema, 4 de abril de 2012, rol $\mathrm{N}^{\circ}$ 10884-11). Por lo tanto, la acción de reparación ambiental por contaminación sonora encubre objetivamente una acción de cesación.

Sin embargo, al ser las personas las que se ven afectadas por el ruido pareciera que la acción de indemnización dice mayor relación con la pretensión de los inmitidos. En virtud del nuevo procedimiento por daño ambiental establecido en la Ley $\mathrm{N}^{\circ} 20.600^{152}$ su ejercicio se torna farragoso. El demandante deberá acreditar en una primera etapa el daño ambiental, operando la inversión de la carga de prueba por infracción de las normas de emisión, ante el Tribunal Ambiental correspondiente. Solo una vez que éste establezca mediante sentencia su acaecimiento es que en un segundo procedimiento conocerá el Juzgado de Letras en lo Civil correspondiente la acción indemnizatoria.

En consecuencia quien entable una acción civil por daños ambientales estará sujeto a un doble procedimiento. El primero ante el Tribunal Am-

${ }^{151}$ El artículo 2 letra s) de la Ley general del medio ambiente define reparación como "la acción de reponer el medio ambiente o uno o más de sus componentes a una calidad similar a la que tenian con anterioridad al daño causado o, en caso de no ser ello posible, restablecer sus propiedades básicas". Se ha reconocido expresamente en la jurisprudencia que el objeto de tutela de la Ley $\mathrm{N}^{\circ} 19.300$ es la vida, salud y equilibrio ecológico (Corte de Concepción, 10 de abril de 2012, rol N²73-2011).

${ }^{152}$ Ley publicada en el Diario Oficial el 28 de junio de 2012 que Crea los tribunales ambientales. 
biental y el segundo en sede civil. Estimamos que el único incentivo para desarrollar dicha estrategia procesal será beneficiarse de la presunción de la responsabilidad ambiental aunque ello no asegure al demandante una sentencia favorable. Su ejercicio no es laudable pues existen otras vías judiciales que tienden al mismo objetivo y que no suponen una carga innecesaria de tiempo, tramitación y recursos.

\section{Procedencia de la acción de responsabilidad extracontractual.}

El ruido produce un daño a las personas que lo sufren. Es difícil imaginar un caso en que el daño recaiga sobre bienes patrimoniales. La contaminación acústica provoca un desmedro en la calidad de vida y salud de quién se expone a ellos y por lo tanto se solicitará su resarcimiento y las medidas tendientes a atenuar sus efectos. Conforme al libro IV título $35^{\circ}$ del Código Civil todo daño debe ser indemnizado y en este supuesto se demandará la compensación de los daños extrapatrimoniales o morales.

Para el caso de inmisiones sonoras la indemnización puede ser solicitada no tan solo por el dueño o poseedor del predio afectado sino todo usufructuario, habitador o arrendatario cuando el daño le significa perjuicio en sus derechos reales. Es atingente con las relaciones de vecindad modernas que deba responder no solo el dueño del predio emisor sino todo aquel que realice la actividad inmitente.

Para que proceda la responsabilidad extracontractual debe existir capacidad, hecho ilícito, un daño y la relación de causalidad ${ }^{153}$. Suponiendo que el autor no es de los incapaces del artículo 2.319 CC., se deberá acreditar que la emisión de ruido efectivamente producido por el daño que se alega, con la posibilidad de utilizar todos los medios de prueba que ofrece el ordenamiento. Sin embargo, algunos autores incluso proponen flexibilizar la prueba del daño moral por ruidos con recurso a la idea que se expresa con la frase "res ipsa loquitur" 154 .

El punto más conflictivo lo representa el hecho ilícito. Probablemente al entablar una acción de indemnización por responsabilidad extracontractual el demandado se defienda alegando que no ha actuado con culpa o dolo pues-

${ }^{153}$ Alessandri Rodríguez, Arturo, De la responsabilidad extracontractual en el derecho civil chileno (Santiago, Editorial Jurídica de Chile, 2005), p. 95.

${ }^{154}$ Martí Martí, J., cit. (n. 110), pp. 111-112, quien, en realidad, utiliza la expresión "iure ipsa loquitur". Sin embargo, se trata de un error, porque, en conformidad con Herrero Llorente, Víctor José, Diccionario de expresiones y frases latinas (2a edición, Madrid, Gredos, 1985), p. 336, la expresión latina correcta es "res ipsa loquitur". Por otro lado, la locución citada tendría que ser "ius ipsum loquitur". El pronombre "ipsa” es femenino (en tanto que "ius" es neutro), y por ello concuerda con "res" que también es femenino. 
to que no ha sobrepasado el límite administrativo permitido en el Decreto Supremo $\mathrm{N}^{\circ} 146$ o la respectiva ordenanza local ${ }^{155}$. Por ejemplo, en una zona habitacional durante las 7 y 21 horas se permite un nivel máximo de presión sonora corregido de 55 decibeles. ¿ $\mathrm{Si}$ el emisor durante el mismo periodo de tiempo genera ruidos constantes de 54 decibeles se encuentra exento de responsabilidad ${ }^{156}$, o bien si un municipio mediante Decreto suspende la ordenanza de ruidos para que se desarrolle un evento ruidoso en su comuna ¿el afectado quedará impedido de tutela?

Estimamos que el derecho privado y el derecho público actúan en ámbitos diversos y con finalidades distintas. Algunos postulan que sería el derecho público el encargado de regular las emisiones y el derecho civil las inmisiones ${ }^{157}$.

Si bien en algunos casos la administración establece parámetros que limitan actividades, éstos no pueden ser los mismos con los que se sirva el ordenamiento privado para determinar si una conducta es lícita o no. Es inviable la "administrativización el Derecho Civil"158 pues lo tolerable en las relaciones de vecindad no se determina a priori por normativa pública sino en el estudio del caso concreto particular. El cumplimiento de un decreto por parte del emisor no puede despojar a un tercero de su legítimo derecho de solicitar tutela civil ante una inmisión intolerable ${ }^{159}$. Los ámbitos jurídicos no son excluyentes sino complementarios.

La normativa de ruidos es el mínimo exigible para efectos de desarrollar una actividad en el campo de la normal convivencia y no debe ser concebida como un permiso para perturbar a otros. La emisión encuentra su punto de

${ }^{155}$ En caso contrario el hecho ilícito será más fácil de acreditar.

${ }^{156}$ Hacemos presente que para efectos de precisión terminológica no se puede considerar el ejemplo expuesto como contaminación acústica pues la legislación ambiental, como se ha hecho presente anteriormente, solo estima que existe contaminación cuando la entidad del ruido sobrepasa los límites establecidos en la legislación vigente lo que no ocurre en el caso en comento. Sin embargo Bertelsen Repetto, R., cit. (n. 140), p. 156 manifiesta que las definiciones de la Ley $\mathrm{N}^{\circ} 19.300$ no son interpretativas de la Constitución por lo que nada impide que los tribunales de protección lo entiendan de manera distinta.

${ }^{157}$ Navarro Mendizabal, I. A., cit. (n. 12), p. 30. En el mismo sentido Egea FERnÁNDEZ, J., cit. (n. 76), p. 19.

${ }^{158}$ Díaz Romero, M. del R., cit. (n. 36), p. 48.

${ }^{159}$ Díaz Romero, M. del R., cit. (n. 36), p. 49, expone enfáticamente que la normativa "resulta insuficiente para proteger los intereses de los particulares, ya que la regulación administrativa no es, ni puede ser, exhaustiva, sus enumeraciones de inmisiones son ejemplificativas y el cumplimiento de los Reglamentos o la obtención de licencia administrativa no supone que la inmisión dañosa pueda considerarse legítima desde el punto de vista civil, ni exonera, por tanto, de tomar las medidas oportunas y de exigir responsabilidad". 
partida en la regulación administrativa y su límite en la afección a terceros. Aunque no se vulnere la normativa pública siempre deben procurarse las medidas necesarias para evitar causar perturbaciones a terceros. Hace casi un siglo atrás Claro Solar enseñaba que “[...] no serviría de excusa al propietario que causa el perjuicio o molestia al vecino, el haber obtenido de la autoridad administrativa el permiso que los reglamentos exigen para la instalación de ciertos negocios o industrias, fábricas o usinas. Tal autorización no podría poner a cubierto al industrial de la acción civil de sus vecinos" ${ }^{160}$. Sin embargo otros connotados autores señalan que ante la inmisión de una actividad autorizada por la administración solo se podrá pretender una indemnización y no la cesación, lo que en principio nos genera más de alguna duda ${ }^{161}$.

En España gran parte de los procedimientos relativos a inmisiones han sido resueltos mediante la responsabilidad aquiliana ${ }^{162}$. La dificultad supone determinar cuando la inmisión es intolerable, indeseada o perjudicial. El criterio de inmisión observado no debe ser cuantitativo sino cualitativo ${ }^{163}$ pues independiente de la envergadura del daño lo trascendente para el juez será determinar la licitud de la acción u omisión.

En síntesis, el emisor de los ruidos que afecte los derechos del dueño, poseedor o mero tenedor de un inmueble ajeno indefectiblemente estará sujeto a las normas de responsabilidad extracontractual previstas en el ordenamiento común pudiendo el afectado solicitar el resarcimiento del mal causado y las medidas tendientes a su morigeración.

\section{De las acciones posesorias.}

Hemos dicho que las inmisiones, en particular la sonora, turban la posesión del poseedor pues impide un libre y pacífico goce del inmueble. Las acciones posesorias tienen por finalidad conservar la posesión de bienes raíces o de los derechos reales constituidos en ellos ${ }^{164}$.

Autores nacionales autorizados destacan que las acciones posesorias “[...] encuentran su razón de ser en la paz social. Impiden que los particulares, con prescindencia de la autoridad del Estado, se hagan justicia por sí mismos y alteren, por obra de sus solos medios, la situación de hecho existente relativa a los inmuebles" 165 . Así también ha sido entendido por la Corte Suprema

${ }^{160}$ Claro Solar, L., Explicaciones, cit. (n. 10), VI, p. 354, núm. 303.

${ }^{161}$ Alessandri, A. - Somarriva, M. - Vodanovic, A., Tratado, cit. (n. 3), I, p. 102 n. 141.

${ }^{162}$ Macías Castillo, A., cit. (n. 8), p. 43.

${ }^{163}$ Ibíd., p. 257.

${ }^{164}$ Artículo 916 CC.

${ }^{165}$ Alessandri, A. - Somarriva, M. - Vodanovic, A., Tratado, cit. (n. 103), II, p. 305 n. 1.251 . 
desde ya mediados del siglo pasado ${ }^{166}$. Del mismo modo, quien inmite altera fácticamente la posesión ajena transgrediendo la paz de la comunidad. Las acciones posesorias son compatibles con la teoría de las inmisiones al converger en su fundamento social. Continuar obviando que el inmitido puede ejercer las acciones posesorias en ocasión de molestias extrañas significa relegarlo a las vías administrativas, tribunales de protección, la autotutela o, en definitiva, al éxodo ${ }^{167}$.

Por los actos de molestia, turbación o embarazo que faculta el ejercicio de estas acciones se entiende "todo acto o hecho voluntario, realizado de buena o mala fe, que, sin despojar a otro de su posesión, la contradice e implica disputar el derecho que pretende tener el poseedor de ejercerla"168. Tal definición se ajusta a los actos inmisivos toda vez que su origen es un acto humano, no despojan la posesión ajena sino que la molestan, la contradice al alterar la situación de hecho y disputan fáctica, no jurídicamente, el derecho del poseedor pues impide que lo ejerza de manera plena independiente del título jurídico en que se ampare ${ }^{169}$.

${ }^{166}$ La Corte Suprema, 6 diciembre 1965, en Revista de Derecho y Jurisprudencia, 62 , sec. $1^{\text {a }}$, p. 459 , ha señalado que "desde el Derecho Romano y a través de toda la legislación universal se reconoce, sin la menor duda sobre el particular, que las acciones posesorias -como su nombre lo indica- están dirigidas al mantenimiento de una situación de hecho, que exige la necesidad social dirigida a la conservación del orden público, mediante la substitución de los órganos públicos a la voluntad de los particulares, sin la cual se retrogradaría la justicia directa de los pueblos primitivos, que es la negación del orden jurídico, fundamento indispensable de la convivencia colectiva".

${ }^{167}$ Ya veíamos en el acápite III,1 anterior que en el mismo pasaje del Digesto que da origen a la teoría de las inmisiones el propio jurista romano predica que de no mediar servidumbre para la turbación, el interdicto que el inmitido debe utilizar es el uti possidetis porque no se puede impedir a otro utilizar lo suyo como quiera. Dicha acción que tendía a conservar la posesión es el antecedente directo de nuestra querella de amparo. Véase: Claro Solar, L., Explicaciones, cit. (n. 101), IX, pp. 467-471 n. 1.808.

${ }^{168}$ Alessandri Rodríguez, A., Curso de derecho civil. Los bienes y los derechos reales, cit. (n. 83), p. 884 n. 1.221 .

${ }^{169}$ De hecho, Alessandri Rodríguez, A., ibíd., pp. 885-886 n. 1.221 ilustra al lector con ejemplos prácticos en que las acciones posesorias son procedentes ignorando que son casos clásicos de inmisiones vecinales. Así, señala que proceden las acciones posesorias "si las trepidaciones de los dinamitazos hechos en una mina provocan el desarraigo de los árboles o la quiebra de los vidrios situados en el fundo ajeno, hállese éste, por otra parte, vecino o no a la mina; [...] si hace trabajos en su fundo que provocan en el del vecino hundimientos o inundaciones, etc." Dejamos constancia que la definición de Alessandri ha sido cuestionada por Amunátegui Perelló, C. F., No siendo contra derecho ajeno, cit. (n. 28), p. 520, puesto que considera que su orientación es únicamente al despojo y no a la turbación de la posesión. El autor cita el concepto de Peñailillo el cual evidentemente se encuentra influenciado por Alessandri. No obstante comulgamos con las palabras de Amunátegui Perelló, C. F., Las relaciones de vecindad, cit. 
Es de toda lógica reconocer que los humos que destruyen la capacidad agrícola de un predio o los ruidos que impiden el descanso familiar representan una grave turbación al goce de una propiedad y, por subsiguiente, es aberrante considerar que en esos supuestos existe una posesión plena puesto que dichas inmisiones impiden que el inmueble cumpla con finalidad social, económica y personal para la que ordinariamente se destinan ${ }^{170}$.

Los juicios posesorios tienen la ventaja que se sustancian en procedimientos breves, sumarios y concentrados, con cobro de costas para la parte vencida $y$ se reserva las acciones ordinarias para quienes resulten condenados ${ }^{171}$.

Para efectos de impedir que ruidos perturben la posesión, la acción de amparo que en términos procesales se denomina querella, resulta idónea. Conforme a los artículos 921 CC., ésta tiene por objeto solicitar que no se turbe o embarace la posesión, indemnizando el daño recibido y se dé seguridad contra el que fundadamente teme. Admite solicitar las medidas necesarias tendientes a poner término al ruido que perturba o molesta la posesión del vecino "asegurándolo en la conservación del estado en que se encontraba antes de la perturbación" ${ }^{172}$, la indemnización correspondiente y que se dicten las precauciones necesarias para que no vuelva a ocurrir. En estricto rigor, esta acción recoge todos los elementos necesarios para proteger a la persona y la propiedad inmitida ${ }^{173}$.

(n. 2), p. 108 cuando expone que "durante el siglo XX la comprensión de la función de la querella de amparo se ha visto más bien oscurecida, toda vez que la doctrina ha tendido a ignorar buena parte de la función protectora de la acción, limitando su aplicabilidad sólo a aquellos casos en que el turbador intenta sustituirse al poseedor en el control de la cosa. La idea proviene de la adopción por parte de Claro Solar de las ideas francesas sobre dicho interdicto y ha limitado fuertemente el alcance del mismo [...]". Esperamos que sea una tendencia que vaya en declive y florezca una nueva e idónea lectura respecto de la importante utilidad que representa la querella de amparo como tutela posesoria ante las inmisiones.

${ }^{170}$ Para reforzar la idea que las inmisiones sí suponen la turbación del goce de una propiedad vecina exponemos un pasaje del autor Claro Solar, L., Explicaciones, cit. (n. 10), VI, p. 350, n. 302: "un propietario, por ejemplo, instala una industria, una fábrica o una usina, que produce olores, humos, ruidos que perjudican a los vecinos; los ruidos, porque hacen imposible o sumamente molesta de vivienda en la casa vecina, que puede ser un hotel, cuya clientela disminuye por esta causa [...] perturban y contaminan la atmósfera en el espacio que pertenece al propietario impidiéndole gozar de su predio [...]. Daños de orden puramente material que no es lícito al propietario causar al vecino y que limitan, por lo mismo, el ejercicio del derecho de propiedad [...]".

${ }^{171}$ Artículos 549 y siguientes CPC.

${ }^{172}$ EgAÑA, M. S., cit. (n. 83), p. 185.

${ }^{173}$ En el mismo sentido Amunátegui Perelló, C. F., No siendo contra derecho ajeno, cit. (n. 28), pp. 519 ss. 


\section{CONCLUSIONES}

Las relaciones de vecindad encuentran su fundamento en el derecho ajeno como límite al carácter absoluto de la propiedad. La teoría de la inmisión es una vertiente de éstas cuya fuente normativa existe en el Código Civil pero que lamentablemente ha sido históricamente relegada al olvido por nuestra doctrina y jurisprudencia.

El ruido, como fenómeno inmisivo, ha devenido en un problema cotidiano de la convivencia. Indudablemente que su acaecimiento se incrementará con el paso de las décadas y las pugnas vecinales por este tipo de turbación se exacerbarán. El ruido molesto en nuestra sociedad es sintomático de la modernidad pero no por ello debemos desistir del esfuerzo por moderar su nocividad.

A nuestro parecer no es idóneo ni lógico que la víctima del ruido carezca de facultades en el ámbito civil para solicitar la protección de sus derechos ante los tribunales ordinarios de justicias. A pesar que las turbaciones sonoras no son acervo exclusivo del ordenamiento jurídico privado, su relectura a la luz de la teoría de las inmisiones admite afirmar que existen diversos mecanismos de orden privado que el agraviado por ruidos puede ejercer para la tutela de sus intereses.

\section{BiBLIOGRAFÍA}

Alessandri Rodríguez, Arturo, Curso de derecho civil.Los bienes y los derechos reales (3 $3^{a}$ edición, Santiago, Editorial Nascimento S.A, 1974).

Alessandri Rodríguez, Arturo, De la responsabilidad extracontractual en el derecho civil chileno (Santiago, Editorial Jurídica de Chile, 2005).

Alessandri, Arturo - Somarriva, Manuel - Vodanovic, Antonio, Tratado de los derechos reales. Bienes (6a edición, Santiago, Editorial Jurídica de Chile, 2001).

Algarra Prats, Esther, La defensa juridico-civil frente a humos, olores, ruidos y otras agresiones a la propiedad y a la persona, (Madrid, Mc-Graw-Hill, 1995).

Amunátegui Perelló, Carlos Felipe, El artículo 921 del Código Civil y la querella de amparo. Posibilidad de exigir indemnizaciones a propósito de actos inmisivos, en Corral Talciani, Hernán y otros (editores), Estudios de derecho civil. Jornadas de derecho civil 2005-2009 (Santiago, Legal Publishing Chile 2011) I.

Amunátegui Perelló, Carlos Felipe, Las relaciones de vecindad y la teoría de las inmisiones en el Código Civil, en Revista de Derecho de la Pontificia Universidad Católica de Valparaiso, 38 (2012) 1.

Amunátegui Perelló, Carlos Felipe, No siendo contra derecho ajeno: hacia la formulación de una teoría de las inmisiones en nuestro código civil en Revista Chilena de Derecho, 36 (2009) 3.

Appert, M. Georges, De los derechos del propietario respecto de sus vecinos, ahora, en Tavolari, Raúl (director), Revista de Derecho y Jurusprudencia. Ediciones Bi- 
centenario. Doctrinas esenciales, Derecho Civil, Bienes (Santiago, Thomson Reuters Puntolex, 2010).

BeCK, UlRICH, La sociedad del riesgo. Hacia una nueva modernidad (Barcelona, Paidos, 1998).

Bertelsen Repetto, Raul, El recurso de protección y el derecho a vivir en un medio ambiente libre de contaminación. Examen de quince años de jurisprudencia, en Revista Chilena de Derecho, 25 (1998) 1.

Brizuela, Mónica, Contaminación sonora. Efectos del ruido ambiental en la salud infantil, ahora en, AA.VV., Manual de salud ambiental infantil para enseñanza de grado en Escuelas de Medicina (Santiago, LOM Ediciones, 2009).

Cabanillas Sánchez, Antonio, La reparación de los daños al medio ambiente (Pamplona, Aranzadi, 1996).

Claro Solar, Luis, Explicaciones de derecho civil chileno y comparado (Santiago, Imprenta Nascimento, 1930), VI.

Claro Solar, Luis, Explicaciones de derecho civil chileno y comparado (Santiago, Imprenta Nascimento, 1935), IX.

DíAz Romero, María del Rosario, La protección jurídico-civil de la propiedad frente a las inmisiones. Especial referencia a la acción negatoria (Madrid, Civitas, 2003)

Díez-Picazo, Luis, Fundamentos del derecho civil patrimonial (Madrid, Editorial Tecnos, 1983), II.

EgAÑA, Manuel Simón, Bienes y derechos reales (Caracas, Editorial Criterio, 1964).

Egea Fernández, Joan, Acción negatoria, inmisiones y defensa de la propiedad (Madrid, Marcial Pons, 1994).

Environmental Health Inequialities in Europe. Assessment report World Health Organization. Regional office for Europe, 2012, disponible en http://www.euro. who.int/_data/assets/pdf_file/0010/157969/e96194.pdf, (consulado el 21 de diciembre de 2012).

Figueroa Yáñez, Gonzalo, Curso de derecho civil ( $3^{a}$ edición, Santiago, Editorial Jurídica de Chile, Santiago, 1995), I.

García Ureta, Agustín, El ruido ante el Tribunal Europeo de Derechos Humanos. Otra llamada de atención a la jurisdicción contencioso-administrativa (y también al Tribunal Constitucional): Comentario a "Martinez Martínez v. España", sentencia del TEDH de 18 de octubre de 2011, en Revista Actualidad Jurídica Ambiental, 7 (2011).

Grau, Juan, Contaminación del aire y ruido. Análisis y soluciones de la contaminación atmosférica, acústica y radioactiva (Santiago, Ediciones OIKOS Ltda, 1981).

Herrero Llorente, Víctor José, Diccionario de expresiones y frases latinas (2a edición, Madrid, Gredos, 1985).

IÑIgueZ, Rodrigo y otros, Medición de los niveles de ruido ambiental en la ciudad de Santiago de Chile, en Revista de Otorrinolaringología y Cirugia de Cabeza y Cuello, 67 (2007) 2.

Labbé Opazo, Francisco, Censo 2012. Resultados preliminares censo depoblación y vivien$d a$, Instituto Nacional de Estadística, disponible en http://www.censo.cl/2012/08/ resultados_preliminares_censo_2012.pdf, (consultado el 25 de enero de 2013).

Macías Castillo, Agustín, El daño causado por el ruido y otras inmisiones (Madrid, La Ley, 2004).

MARTí MARTí, Joaquim, La defensa frente a la contaminación acústica y otras inmisiones (Barcelona, Bosch, 2008). 
Martín Mateo, Ramón, Tratado de Derecho ambiental (Madrid, Editorial Trivium S.A., 1992), II.

Navarro Mendizabal, Iñigo Alfonso, Las inmisiones y molestias medioambientales. Tutela civil preventiva (Madrid, Editorial Dykinson, 1996).

Peñailillo Arévalo, Daniel, Los bienes. La propiedad y otros derechos reales (Santiago, Editorial Jurídica de Chile, 2006).

Pescio Vargas, Victorio, La vecindad (Santiago, Editorial Jurídica de Chile, 1952). Ponce, Marcela, Informe del estado del medio ambiente 2011 (Santiago, A. Molina S.A., 2012).

Vial del Río, Víctor, Teoría general del Acto jurídico (4ª edición, Santiago Ediciones Universidad Católica de Chile, 2000). 
